\title{
ARTIGOS
}

\section{HISTORIA DA PALESTINA NOS TEMPOS DO NOVO TESTAMENTO (IV).}

\section{(Continuação) .}

\section{§ 4. - Territórios de Herodes.}

283. - Antes de abordamos o estudo do govêrno de Herodes no período de esplendor de seu poder, de c. de $28 / 7$ a $14 / 13$ a. C. (n. 174), e dentro dos limites impostos à sua soberania por Roma $(\S 3)$, será útil apresentar uma visão de conjunto dos diversos territórios sucessivamente cedidos a êle por Marco Antônio e Augusto, para melhor entendermos o papel que lhe coube como governante de um conglomerado de regiões habitadas por populações de raças e culturas diferentes, e ambientadas em quadros geográficos diversos, com as respectivas condições econômicas próprias. Êste exame nos ajudará a compreender, sem mais, as diferentes mudanças que se deram depois da morte de Herodes, na organização política da Palestina, quando ela, seja tôda, seja em parte, passou, primeiramente, a diversos de seus descendentes, e, por duas vêzes, esteve sujeita parcialmente a procuradores romanos antes de se ver tôda ela definitivamente incorporada por Vespasiano ao sistema provincial romano, depois da guerra de 66-70 d. C.

284. - Estes diversos territórios abrangiam, com efeito, distritos inteiramente judaicos, e outros inteiramente helenizados, ou, então, em vias de franca helenização, além de regiōes de população mista, judaica, helenizada e nômade (1). Este fato exigia, por parte do rei, a manutenção, ou, então, conforme o caso, a instituição de regimes administrativos diversos: o regime centralizado, herdado dos Ptolomeus e dos Selêucidas, e o regime das cidades de tipo helenístico, até certo ponto autônomas. Além disto, com o crescimento gradual do reino, e o acréscimo de distritos de populações mais ou menos nômades e pouco inclinadas a submeter-se aos costumes civilizados das culturas helenística e judaica, exigia-se uma adaptação às exigências do momento.

(1). - Tomamos aqui em sentido mais ou menos idêntico os adjetivos grego, helenizado e helenístico, tratando-se sempre de cidades ou distritos de população indigena, mesclada de gregos, que haviam aceito a cultura grega. Sôbre a maior ou menor penetração desta, em seus diversos aspectos, nos diferentes territórios do Império, ver A. H. M. Jones, The Greek City from Alexander to Justinlan, Oxford, 1940, 277.295. 
Estas circunstâncias deviam dificultar a atividade de Herodes como rei aliado de Roma, ou seja, sua ação unificadora e estabilizadora, como preparação gradual para a incorporação definitiva da Judéia ao Império (n. 230), e deviam exigir dêle o máximo de seus esforços.

285. - Veremos, contudo, que êle, homem enérgico e ambicioso (n. 99s), soube, a seu modo, desempenhar-se satisfatòriamente de sua missão, e corresponder às esperanças, que Roma nele depositava. E' por isto mesmo que via seus territórios várias vêzes aumentados, e novos distritos, até então irrequietos, e avessos aos costumes de uma comunidade organizada, entregues à sua ação, inicialmente policial, mas, sobretudo, estabilizadora (n. 266s). A seqüência, todavia, da história da Palestina mostra que esta ação não foi duradoura, e que o edifício, erguido e mantido à fôrça, ameaçou desabar logo depois de sua morte. A intervenção enérgica de Roma na pessoa de Públio Quintílio Varo, governador da Síria (6-4 a. C.), conseguiu adiar sua ruína completa por mais algumas dezenas de anos. Era ta$r \in f a$ demasiadamente difícil amalgamar, dentro de pouco tempo, elementos tão diversos, como os descrevemos, e a helenização forçada da Palestina não fêz senão reavivar a reação judaica, que fôra, de certo modo, declinando depois da luta heróica dos macabeus. Não foram as medidas policiais de Herodes e seus métodos de fôrça bruta capazes de conter indefinidamente a reação do povo judaico, ainda mais que êle não deixou um herdeiro capaz de continuar a obra iniciada. Foi, aliás, o próprio Augusto que achou conveniente dividir o reino em três partes independentes, quando Herodes teria preferido deixá-lo a um só de seus filhos, o qual tivesse debaixo de si os outros dois como reis ou tetrarcas-vassalos (n. 247).

286. - I. A expansão territorial do reino de Herodes até Augusto. - Os territórios iniciais do reino de Herodes compreendiam, antes de tudo, os distritos da Palestina, que haviam sido deixados por Pompeu, depois de cerceados consideràvelmente em alguns pontos vitais, a Hircano II, reinstalado como sumo-sacerdote e chefe da nação (n. 14), quando fôra rei e sumo-sacerdote, antes de se ver deposto por seu irmão 'Aristóbulo II (n. 12). Pompeu, com efeito, concedeu liberdade às cidades marítimas de Rafia, Gaza, Antedón, Aretusa, Jafa, Apolônia, Tôrre de Estratão e Dora, e, no interior, às cidades de Maresa e Adora, na Iduméia (n. 234), de Iâmnia e Azoto, na planície da Shefelah, à cidade da Samaria com seu distrito, no centro do país, a Citópolis ( = Beisan), na planície de Esdrelón (= Baixada 
Grande), a Hipos, Gádara, Pela e Dium na Transjordânia (2). Da localização exata de tôdas elas, entre as quais algumas se tornaram famosas como centros comerciais, industriais e literários, bem como de suas relações com o Império e a província da Síria, tratar-se-á no capítulo relativo às cidades da Decápole, e às outras cidades livres da Palestina, enquanto mais adiante se examinarão as relações entre Herodes e aquelas cidades livres, que pouco a pouco lhe foram concedidas por Marco Antônio e Augusto. Diremos, outrossim, em que sentido se deve tomar o conceito de liberdade política ou autonomia, concedida às cidades mencionadas. Em todo o caso, diante da perda de Jafa, 'via-se o estado judaico novamente privado do livre acesso ao mar, e ainda mais, rodeado, por todos os lados, de cidades livres, na maioria helenísticas, que não só lhe tolhiam os movimentos, mas ainda lhe apregoavam em altos brados a superioridade da cultura helenística e do regime politico correspondente. Destarte o reino dos hasmoneus, construído à custa de grande heroismo e de muito sangue, pelos antecessores de Hircano II, via-se reduzido, no dizer de José, aos próprios confins (A. $14,4,4 \S 74 ;$ G. $1,7,7 \S 155$ ), isto é, aos territórios pròpriamente judaicos. Esperava-se, quiçá, que a influência das cidades helenísticas acelerasse a assimilação da Judéia ao resto do Império, que já começava a delinear-se e viria a constituir-se definitivamente com o advento de Otaviano Augusto.

287. - Por cúmulo da desgraça, os territórios judaicos ainda se viam separados entre si por um 'corredor', porquanto o distrito da Samaria, e os territórios das cidades livres de Citópolis e de Pela, ambas da Decápole, separavam a Galiléia da Judéia e da Peréia. Parece, contudo, que o respeito pela soberania romana, mesmo nos tempos da guerra civil, bastava para evitar atritos entre os diversos elementos do conglomerado heterogêneo da Palestina de então, e nada ouvimos, nesta época, sôbre dificuldades, que impedissem o livre trânsito entre os

(2). - A. $14,4,4 \S 73$ s e $5,3 \S 88 ;$ G. $1,7,7 \S 155-157$ e $8,4 \S 166$. Estas quatro listas referem as cidades libertadas por Pompeu, e as reconstruídas por seu legado Gabínio, o que permite integrar a lista referida. Dium só se menciona em A. 14, 4, $4 \S 75$, Apolônia e Adora (ou Adóreos) só em G. $1,8,4 \S 166$, onde também se lê Gámala ou Gábala, em lugar de Gádara, como tem a traduçāo latina, e onde se omite Gaza. A esta lista devem juntar-se, além de Ascaláo, que sempre continuara livre (n. 118), outras cldades autônomas, situadas tôdas na Transjordânia, algumas das quais nunca estiveram sujeitas aos judeus, mas às quaís Pompeu concedeu a liberdade (cf. E. Schürer 3, 120). 
diversos distritos do território judaico, arbitràriamente truncado. Basta recordar as atividades do jovem Herodes como governador da Galiléia (nn. 102-112). (3). Sòmente em tempos posteriores fala-se de distúrbios entre os judeus e seus vizinhos, sobretudo os samaritanos, o que provàvelmente se explica, de uma parte, pela gradual tomada de consciência do caráter peculiar do povo judaico pròpriamente dito, e, de outra, pela crescente absorção dos samaritanos pela cultura helenística (4). Veremos mais adiante, que se tentou enfraquecer, ainda mais, a unidade e coesão do povo judaico, por meio de uma nova divisão administrativa da Judéia pròpriamente dita, da Galiléia e da Peréia. Em grande parté; porém, os próprios chefes romanos constribuiram para que esta nova divisão não durasse por muito tempo, assim como restituiram aos judeus vários distritos, que lhes haviam sido tomados, e pràticamente reconheceram e legalizaram a anexação de grande parte dos territórios, que haviam sido conquistados e judaizados pelos macabeus e hasmoneus.

288. - Com efeito, se José diz, que a ação libertadora de Pompeu reduziu os judeus aos próprios confins (n. 285), ou seja, aos territórios pròpriamente judaicos, é preciso considerar que a etnarquia restituída a Hircano II (n. 14. 19), entregue posteriormente a Herodes sob a forma de um reino, já não se limitava apenas ao território pròpriamente judaico, encontrado pelos macabeus no início de sua revolta contra os opressores de seu povo. Cem anos de conquistas e de dominação haviam conseguido anexar e assimilar ao núcleo inicial de seu domínio regiões relativamente vastas, o que não podia deixar de ser ignorado pelos conquistadores romanos, os quais, reconhecendo, ccm tôda a probabilidade, a judaização efetiva destas regiões, confirmaram os judeus na posse delas.

289. - A própria ação libertadora de Pompeu já havia deixado aos judeus as províncias da Galiléia e da Peréia, além da banda oriental da Iduméia, distritos que haviam sido conquis-

\footnotetext{
(3). - Conforme M. du Buit, Géographic (ver n. 85) 171, o princípio seguido na repartição da Palestina foi o de separar entre si as populações inimigas, judeus, gregos e samaritanos.

(4). - Sóbre as relações entre judeus e samaritanos ver 0 n. 306s. O assassinato de um galileu na Samaria provocou um dos distúrbios que agitaram - pafs durante a época que precedeu a revolta de 66 d. C., G. $2,12,3$ \$ 232-7 § 246; A. 20,6, 1-3. Questões de fronteira entre os habitantes da Peréla e os de Filadélfia-Ammân deram-se em 44. d. C., no tempo to procurador Cúsplo Fado, A. 20, 1, 1.
} 


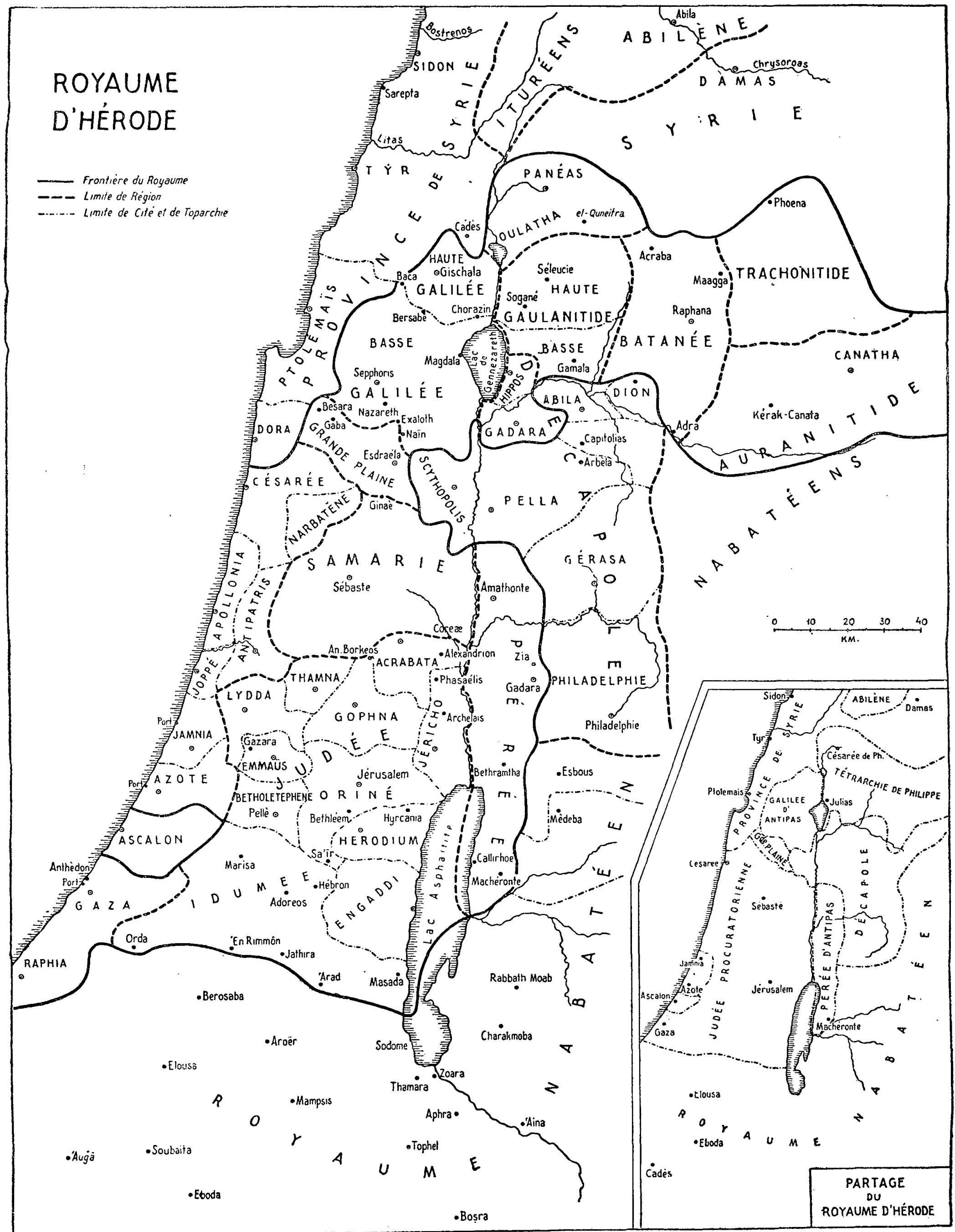


tados e judaizados pelos macabeus e hasmoneus (5). Esta situação foi ainda mais oficializada pela nova divisão administrativa dos territórios judaicos, introduzida por Aulo Gabínio, legado de Pompeu (n. 14. 287). Substituiram-se os antigos distritos administrativos do estado hasmoneu pelos cinco sinodos ou sinédrios de Jerusalém, Gezer e Jericó, na Judéia; de Amatús, na Peréia e de Séforis, na Galiléia (n. 309). Por meio dêste fato reconheceram-se os judeus na posse da Peréia, da Galiléia e da Iduméia oriental, uma vez que Jerusalém servia de centro administrativo para tôda a parte meridional da Judéia. Reconheceu-se, ainda, a posse de Gezer-Gázara e de Jericó, anexadas pelos macabeus e hasmoneus (6). Júlio César, em 47 a. C., além de restituir Jafa aos judeus (n. 19; A. 14, 10, 6 § 202. 205), ainda faz menção de Lida (ib. § 208; cf. ib. $15,3 \S 412$ ), confirmando destarte os direitos judaicos sôbre esta cidade, que encontramos, efetivamente, em poder de Antígono, alguns anos depois (n. 158). Confirma, ainda, a Hircano II e aos judeus a posse das vilas da Baixada Grande de Esdrelón (A. 14, 10, 6 $\S 207$ (7).

290. - Este fato legalizava, por conseguinte, a posse da Baixada Grande, e a anexação de vários distritos que haviam outrora pertencido à Samaria (8). Com efeito, Jonatã Macabeu (160-143 a. C.) obtivera dos reis selêucidas as toparquias ou vouoi samaritanos de Aphairema, Ramathaim, Lydda e Acrábata, como já obtivera antes a cidade e o distrito de Accaron (1 Mac. 10, 89), uma das cinco cidades originais da pentápole dos filisteus (9). Esta mesma anexação é confirmada, em $44 / 3$ a.

(5). - Sôbre as campanhas na Galiléia ver 1 Mac. 5, 9-15. 21-23; A. 12, 8, 2 \$ 332-334; 13, 5, 6 \& 154-7 \& 162; na Transjordânia 1 Mac. 5, 9-15. 24-44; A. $12,8,3 \S 335-340$ e $5 \S 345-347 ; 13,9,1 \S 255$ e $15,4 \S 397$; na Iduméia 1 Mac. 5, 3. 65; A. 13, 9, 1 \$ 257s e 15, 4 \&396; $12,8,1$ \& 328 e 8, 6 § 353; sôbre a conquista de Gezer-Gázara 1 Mac. 13, 43-48; A. 13, 1, 3 $\S 15$, etc.

(6). - Ver 1 Mac. 5, 8; 13, 43-48. 53; 16, 11; A. 13, 1,1 \$ 15, etc.; 2 Mac. $15,1$. Sôbre Jericó 1 Mac. 16, 11-17. Encontrou-se em Gezer um grafito no palácio dos hasmoneus, no qual se roga que fogo destrua êste mesmo palácio. Ver J.-B. Frey, Corpus Inscriptionum Judaicarum II, Città del Vaticano 1952, 225, n. 1184; E. Gabba, Iscrizloni greche e latine per lo studio della Bibbia (Sintesi dell'Oriente e della Bibbia 3), Torino 1958, 31s. Trata-se da referência maís antiga aos macabeus em fontes profanas.

(7). - M. du Buit, ib. 172.

(8). - F.-M. Abel, Géographie 2, $147^{2}$.

(9). - A pentápole dos filisteus: Gaza, Ashdod-Azotos, Eqron-Accaron, GethGath, Ascalāo; F.-M. Abel, Géographie 1, 261-270; M. du Buit, ib. 138-140; Jos. 13, 3; 1 Sam. 6, 16-18; Zach. 9; : ss. 'Como Accaron não aparece entre as cidades libertadas por Pompeu, é possivel que tenha sido posteriormente absorvida por outro distrito. - $\rceil$ Em 1 Mac. 11,$34 ; 10,30.38 ;$. $13,4,9 \S 127$ fala-se apenas em três distritos adquiridos por Jonată; em 
C., pela ação de Cássio Longino, mandando vender como escravos os habitantes de Gofna, Emaus, Lida e Tamna, retardatários no pagamento da contribuição de guerra, imposta por êle aos habitantes da Judéia (n. 114). Sabemos, com efeito, que Emaus tomara o lugar de Gázara-Gezer como capital de distrito; que Tamna substitura a Ramathaim, e Gofna a Aphairema (n. 114). Hircano II, por conseguinte, ao pedir a Marco Antônio a soltura dos vendidos, intercede simplesmente a favor de súditos seus (n. 277). Os romanos, por outro lado, dando-lhe o título de etnarca dos judeus (n. 19. 275), procuraram adaptar-se à realidade, enquanto lhe davam o govêrno de todos os territórios habitados, na maioria, por judeus.

291. - E' nestas condições que Herodes, no pleno vigor de seus vinte e cinco anos (n. 96), enceta, como governador da Galiléia, sua longa carreira política (n. 102). Desempenhando com energia o cargo que lhe coube na parte mais setentrional e mais irrequieta do país (nn. 102.155), foi, pouco depois, nomeado por Sexto César governador da Celessíria e da Samaria (nn. 108. 110 ), isto é, foram-lhe entregues alguns distritos da Decápole, provàvelmente as cidades de Hipos e Gádara (nn. 108. 112. 212), e conferiram-se-lhe, na Samaria, certas atribuições administrativas, que não mais podemos definir (n. 112). Já então tinha êle debaixo de suas ordens um território bastante extenso e contínuo, formando um só bloco, e abrangendo tôda a Galiléia (n. 309), a banda oriental do lago de Genesaré (n. 211), e a Samaria (n. 305). Governava êle êstes distritos em parte na qualidade de governador da Galiléia, nomeado por seu pai Antípater (n. 102); em parte como representante de Sexto César, nas partes sujeitas à província da Síria, isto é, na Samaria, e em Hiipos e Gádara (n. 108. 307), e, enfim, como tetrarca da Galiléia, nomeado por Marco Antônio (n. 126). Desta forma preparava êle a fusão gradual dos diversos distritos da Palestina, judaicos e helenizados, que resultaria, um dia, na posse, livre de tributos, de todo o país, como rei aliado de Roma (n. 234). Esta situação, porém, mudou por completo, ainda que temporàriamente: apenas, com a invasão dos partas, em 40 a. C., e o subseqüente reinado de Antígono, de 40/37 a. C. Viu-se Herodes obrigado a retirar-se para a Judéia e Jerusalém, defendendo-as, durante algum tempo, juntamente com seu irmão Fasael (n.

1 Mac. 11, 57; A. 13, 5, $4 \S 145$ em quatro. Acrábata é proposta como quarto distrito, entre outros, por F.-M. Abel, Géographie 2, 135; id., Les livres de Maccabées, Paris 1949, 216. A Acrabatene menclona-se em 1 Mac. 5, 3. Outras Identificaçōes em H. St. J. Thackeray 7, 250s. 287. 297. 
131-133). Retirou-se, em seguida, para a fortaleza de Masada (n. 133), o que confirma que a parte oriental da Iduméia, com Hebrón e Masada, continuava em poder dos judeus (nn. 131. 133. 234), tendo a parte ocidental, com as importantes cidades de Maresa e Adora, obtido de Pompeu a liberdade, em 63 a. C. (11. 234. 286) .

292. - Nomeado rei dos judeus, em 40 a. C. (nn. 139 . 275), Herodes, abstraindo do parêntesis do govêrno de Antígono, inteiramente ilegal aos olhos dos romanos (n. 139), entrava no pleno gôzo da herança de Hircano II, enquanto lhe fôsse "possivel arrancá-la das mãos de Antígono, já então abandonado pelos partas (n. 150). Orá, depois das amputações 'operadas no território judaico por Pompeu (n. 286), só restavam do reino de Alexandre Janeu (103-76 a. C.), sob o qual o estado hasmoneu havia alcançado sua maior extensão (10), as três regiões seguintes: 1. A Judéia pròpriamente dita, com a parte oriental da Iduméia (n. 131. 133. 234), ou seja, de norte a sul, o vale do Aquém-Jordão, entre a vila de Coréias - кopéa ou кopéa situada perto da fortaleza de Alexandrium (11), até à parte meridional do Mar Morto pouco abaixo de Masada, sem incluir a Bersabé, então em mãos dos nabateus (n. 330); de leste a oeste, o território compreendido entre o Jordão e a cidade de Gezer, ao norte, e o Mar Morto e as cidades livres de Maresa e Adora, mais ao sul (n. 234). - 2. A Peréia, na banda do Além-Jordão, situada entre o território da cidade livre de Pela ao norte, e a fortaleza da Maqueros ao sul (n. 234), limitada a leste pelos territórios das cidades da Decápole e o dos nabateus (n. 313). - 3. Tôda a região da Galiléia, tanto a superior ou montanhosa ao norte, quanto a inferior ou plana ao sul, incluindo, ainda, a planície de Esdrelón ou Baixada Grande (nn. 309-312) (12). - São estas as três regiões de população prevalentemente judaica, que comumente se supõem na Mishnah (13). Não sabemos se Herodes tinha o direito de readquirir o contrôle sôbre aquela parte da Celessíria, que lhe fôra confiada por Sexto César (nn. 108. 110), isto é, sôbre as cidades de Hipos e Gádara (n. 212). Sabemos apenas que, poucos anos depois, partes da Celessíria setentrional, incluindo provàvelmente as

(10). - A. 13, 15, 4 \$ 395-397; F.-M. Abel, ib. 138.

(11). - A. 14, 3, $9 \S 49 ;$ G. $1,6,5 \S 134 ; 4,8,1 \S 449$. No mosaico de Mádaba lê-se Koreous, que se identifica com tell Mazar, perto de Qarawa, na saida do wadi el-Fara; F.-M. Abel, ib. 152. 300s; M. du Buit, ib. 67 .

(12). - Ver a descrição mais exata dos limites da Judéia, da Peréia e da Galìléia em G. 3, 3, 1 \& 35-5 § 56; F.-M. Abel, ib: 147. 152. 154.

(13). - Shebiith 9, 2; Kethuboth 13, 10; Baba Bathra 3; 2; ver E. Schürer 3, 2s. 
cidades mencionadas, foram cedidas a Cleópatra por Marco Antônio (nn. 189. 195. 212).

293. - A cidade de Gaza, libertada por Pompeu, em 63 a. C. (n. 286), encontra-se em mãos de Herodes em 37 a. C., uma vez que êle, pouco depois da conquista de Jerusalém, nomeia seu cunhado Costobar governador da Iduméia e de Gaza (nn. 192. 218). Segue-se daí que esta cidade foi dada a êle, quando foi nomeado rei, em 40 a. C. (n. 192). Perde-la-á pouco depois, devendo cedê-la a Cleópatra. O fato, contudo, de se nomear Costobar governador também da Iduméia, prova que esta havia igualmente sido entregue a Herodes em 40 a. C., tratando-se, no caso, não da Iduméia oriental, que nunca saira das mãos dos judeus, mas, sim, das cidades livres de Maresa e Adora (n. 234. 286). Não iria Herodes nomear a Costobar governador, simultâneamente, de Gaza e da Iduméia oriental, se os dois distritos estivessem separados entre si pelos territórios livres daquelas duas cidades (14) .

294. - Este argumento se confirma pelo texto de Apiano (n. 234), no qual êle nos informa que Herodes fôra nomeado rei por Marco Antônio, para recolher os tributos dos idumeus e dos samaritanos, isto é, que se lhe confiavam os distritos da Iduméia e da Samaria mediante o pagamento de um tributo, du qual foi dispensado por Augusto. Ora, como a Iduméia oriental, com Hebrón e Masada, nunca saira das mãos dos judeus, o texto só pode referir-se à Iduméia ocidental, situada entre os distritos das cidades livres do litoral, e a Iduméia oriental. Trata-se, por conseguinte, de um distrito que havia sido declarado livre por Pompeu, como o fôra a Samaria (n. 286), e era entregue, juntamente com a mesma Samaria, ao poder de Herodes por Marco Antônio. Menciona-se, pois, a nomeação de Herodes em conjunção com aquêles de seus territórios, pelos quais inicialmente devia pagar uma subvenção àquêle triúnviro, e Apiano só aduz, entre outros, o exemplo de Herodes, para provar o fato insólito de se terem nomeado reis aliados tributários, quando êstes costumavam estar isentos do pagamento de tributos (n. 234). Enfim, tinha Herodes ainda direitos sôbre a cidade de Jafa, devolvida por Júlio. César a Hircano II, a fim de lhe proporcionar livre acesso ao mar (n. 289). Herodes a reconquista, antes mesmo de libertar os seus, sitiados em Masada (n. 159). Perdeu-a pouco depois, juntamente com Gaza devendo

(14). - Regendo Costobar todo o sul da Judéia, tornava-se realmente perigoso para Herodes seu flirt político com Cleópatra, n. 218. 
ccdê-la a Cleópatra, o que se prova pelo fato dela lhe ser entregue novamente por Otaviano, depois da campanha final do Egito (n. 211).

295. - Descrevemos acima pormenorizadamente a campanha empreendida por Herodes para conquistar seu reino (nn. 154-168). Deve notar-se, a êste respeito, que êle só encontrou resistência séria nos territórios pròpriamente judaicos, na Galiléia, na Judéia, e em Jafa, cidade de população prevalentemente judaica (n. 302), e que tôda a campanha se reduziu à reconquista dêstes territórios. A Judéia e a Galiléia só lhe caem nas mãos depois de uma resistência renhida, e sempre renovada (15), enquanto na Iduméia, uma vez libertada das fôrças de Antígono (n 156), nada nos consta sôbre uma resistência séria, excetuando levantes ocasionais ou frustrados (G. 1, 17, 2 § 326; n. 164). A Samaria, com sua posição excelente no centro do país, servelhe de quartel-general, de onde parte para as incursões na Galiléia e na Judéia (nn. 156. 158s. 162. 165). Afirma-se, expressamente, que ela se declarara a seu favor (G. 1, 15, 6 § 299) e vimos que o distrito colaborou ativamente para fornecer mantimentos às tropas romanas de Silo (n. 158). A Peréia não se menciona em tôda a campanha, e parece ter seguido passivamente os destinos da Judéia. Começa ela a aparecer na história de Herodes com a guerra contra os nabateus (n. 196). A resistência da Judéia explica-se pela aversão ao estrangeiro e semijudeu (n. 89. 157), pela ineficiência ou negligência dos chefes romanos (nn. 154. 156-158. 162), e pela presença de Antígono, rei por graça dos partas, mas sempre descendente da casa legítima dos hasmoneus. A longa resistência que soube oferecer, prova que seus adeptos não podiam ser poucos.

296. - Contudo, uma vez completada a conquista da Judéia e de Jerusalém, vemos Herodes na posse pacífica dos territórios a êle confiados, a Judéia, a Iduméia, as cidades de Gaza e de Jafa, a Samaria, a Galiléia e a Peréia. O expurgo da nobreza (n. 176), a execução de Antígono (n. 169s. 176), o assassinato de Aristóbulo III e de Hircano II (nn. 183. 199-201), haviam privado o povo judaico de seus líderes naturais. Mariame, que podia avançar direitos sôbre o trono da Judéia (16), e sua mãe Alexandra, haviam sido igualmente sacrificadas (n. 215.

(15). - Galliéla: nn. 155. 159. 161. 164s; Judéla: n. 156 (Jafa). 157. 164-168.

(16). - Cf. n. 179. Mais tarde Alexandre, filho de Herodes e de Mariame, dirá que seu pai, depols de matar a mãe, queria roubar a ele e a seu irmão o reino dela (G. 1, 26, 1 \& 519; cf. $\$ 521$ ). O exemplo de Alexandra Salomé (n. 11s) podia servir de precedente. 
217). Acresce que as contínuas revoltas e guerras haviam esgotado o povo, e podemos bem imaginar que o entusiasmo anterior cedera o lugar a um cansaço geral e profundo (17). Daí em diante, com efeito, só ouvimos falar de um levante na Judéia por ocasião da viagem de Herodes para junto de Marco Antônio em Laodicéia da Síria, levante em que esteve implicada uma irmã de Antígono (n. 187s), e de uma conspiração frustrada na Iduméia, chefiada por Costobar, cunhado de Herodes. Pouco tempo depois haveria Herodes de perder Gaza e Jafa, devendo cedê-las a Cleópatra, juntamente com o distrito de Jericó (n. 192. 290), conservando embora o contrôle sôbre êste último mediante o pagamento de uma soma anual (n. 190).

297. - Está fora de dúvida que o centro político e religioso dos diversos territórios de Herodes sempre foi a Judéia - i 'Tovóaia - território destacado da província da Samaria - Shamerain -, e organizado, sob o nome de Yehud, por Esdras e Neemias, depois da volta do exílio da Babilônia, em 538 a. C., como parte da quinta satrapia persa de Abarnahará, em parte do anterior reino de Judá (18). Yehudah designava pròpriamente o território da tribo de Judá (Jos. 15, 15; Jdc. 1, 3, etc.), e posteriormente o do reino de Judá (Is. 3, 8; 44, 26; Jer. 23, 6, etc.), que abrangia os distritos das tribos de Judá, Simeão e Benjamim (3 Reg. 12, 20s. 17) (19). O têrmo 'Iovoaia é pròpriamente um adjetivo feminino, derivado do aramaico Yehuday $=$ judeu (20). Da forma enfática do plural aramaico yehudayê derivouse o grego 'Iovóîo, que produziu, por sua vez, Judaei em latim, e as formas correspondentes nas línguas modernas (21). No No-

(17). - J. Klausner, Jesus von Nazareth, 3. ed., Jerusalém 1952, 192.

(18). - Ver F.-M. Abel, Géographie 2, 83-93: royaume de Juda; 105s. Juda sous les Assyriens; 108-123: la Palestine sous le Perses; M. du Buit, ib. 157169; G. Ricciotti 99-158. - Abarnahará (aramaico) $=$ Além do Rio $=\mathbf{a}$ Transeufratene; cf. Heródoto, Historiae 3, 91. O nome respectivo em hebraico aparece em 3 Reg. 5, 4; Esd. 4, 10s. 20; 5, 3, 6;6, 6. 8. 13; 7, 21. 25. Yehud aparece em Dan. 2,$25 ; 5,13 ; 6,14$; Esd. $5,1.8 ; 7,14$; em moedas, papiros, etc., F.-M. Abel, ib. 120; A. Reifenberg, Moedas dos Judeus (trad. hebr.), Jerusalém 1947, 33, e prancha 1, n. 1-3; id., Ancient Hebrew Arts, New York 1950, 55. - Iouda pela Judéia pròpriamente dita: Mich. 5, 1; 1 Mac. 1, 30. 44 (46); Lc. 1, 39; Mt. 2, 6, etc.; Yehudah pela província da Judéla debaixo dos persas Esd. 1, 2s; Agg. 1. 1. 14; 2, 2; Neh. 5, 14, etc.

(19): - A tribo de Simeão foi pouco a pouco absorvida pela tribo de Judá; ver Jos. : 19, 1-9; Gen. 49, 5-7; F.-M. Abel, Géographie 2, 50; M. du Buit, ib. 124-127. 157. Não se menciona na bênção de Móisés em Dt. 33; 6-25.

(20). - Ver Dan. 3, 8. 12; Esd. 4, 12. 23; 5, 1. 5; 6, 7s. 14. Em cuneiforme yaudai; em hebraico yehudi, plural yehudim: 1 Par. 4, 18; 2 Reg. 16, 6; 25, 25; Neh. 1,$2 ; 3,33$, etc.

(21). - Ver Neh. 4, 12; 6, 7; Dan. 3, 8, etc.; no Novo Testamento: Mt. 27, 11. 29. 37 ; Mc. 7,3 ; 15,2 . 9 . 12. 18 , etc. 
vo Testamento ainda aparece 'Iovoaia como adjetivo feminino, acompanhando substantivos, que designam o país, como $\chi$ ẃpa (Mc. 1,5) e $\gamma \hat{\eta}($ Jo. 3, 22; cf. 2 Mac. 1, 1), mas já na tradução dos Setenta e nos Livros dos Macabeus $\dot{\eta}$ 'Iovdaía se encontra como stibstantivo para designar o reino de Judá, ou o país dos judeus, ou seja, a Judéia, (1 Sam. 23, 3; 27, 6. 10, etc. 2 Mac. 1, 1. 10). 'Iovóaia como substantivo, tanto para designar a Judéia pròpriamente dita, quanto a Palestina tôda, encontra-se nos escritores gregos, sobretudo alexandrinos, nos autores romanos e no Novo Testamento (22).

298. - Conforme José, foi o papel preponderante que a tribo de Judá desempenhou na restauração nacional que fêz com que o nome dela passasse a designar todo o país, e que os descendentes das doze tribos em geral passassem a chamar-se simplesmente de judeus (A. 11, 5, $7 \$ 173$ ), como de fato designam-se como tais todos os repatriados no tempo de Nehemias (Neh. $1,2 ; 3,33 ; 4,12 ; 6,7)$, e os judeus da Babilônia e do Egito (23). Parece, com efeito, que fora grande número de sacerdotes e levitas, descendentes, por conseguinte, da tribo de Levi e da família de Arão, só membros das tribos de Judá e Benjamim, ou seja, das tribos que haviam integrado o anterior reino de Judá, tinham voltado do exílio para a terra de seus pais (Esd. 2, 1-70; 8, 1-20; Neh. 1, 5; 7, 6-60; 11, 4-36) (24). Já as guarnições judaicas da ilha de Elefantine e de Siene (= As-

(22). - F.-M. Abel, Géographie 1, 314s. Ver Eupólemo (s. II a. C.), citado por Cornelio Alexandre Polihistor, Fragmento 18 (C. Múller, Fragmenta Historicorum Graecorum III, Parisiis 1883, 225s; Plínio, Naturalis Historia 5, 14, 70: Supra Idumaeam et Samariam Judaea longe lateque funditur. Par ejus Syriae juncta Galilaea vocatur, Arabiae vero et Aegypto proxima Peraea... Reliqua Judaea dividitur in toparchias decem; cf. 5, 12, 67. - Vejam-se também as moedas de Vespasiano, com a legenda: Judaea capta, em A. da Veiga Coimbra, Noçóes de Numismática I (Coleção da 'Revista de História' XI), iSão Paulo, 1957, 216, etc. - Judéia em sentido próprio encontra-se também em Lc. 5, 17; Act. 2, 9; em sentido largo Lc. 1,$5 ; 7,17 ; 23,5$; Act. !10, 37; 11, 29, etc.

(23). - Na Babilônia: Est. 2, 5; 3, 4; 5, 13 (Mardoqueu, da tribo de Benjamim); 8, 1; no Egito: 2 Mac. 1, 1, 10; em geral: 1 Mac. 2, 23; 8, 20. 23. 25. 27. 29. 31, etc. Por outro lado têm os judeus da Palestina a certeza de representar o povo de Israel, a casa de Jacó, etc.: I Mac. 1, 12. 19.49. 56; Jdt. 4, 9, etc. Esta segurança é compreensível depois da conquista da Slamaria e da Galiléia, onde haviam ficado muitos resíduos das dez tribos do reino de Israel. Ver também Cássio Dión, Historia Romana 37, 16, 5-17, 1: Foi isto que se deu ;naquele tempo na Palestina, pois assim desde antigamente se chama todo o povo desde a Fenicia até ao Egito, ao Iongo do mar interior. Êles têm também um outro nome que adquiriram. O país chama-se de Judéia, e êles mesmos de juđeus. Não sei como êste nome lhes foi dado, que se aplica também aos outros homens, mesmo estrangeiros, que abraçam seus costumes.

(24). - G. Ricciott1 107; M. du Buit, ib. '168. 170. 
suân), entre 586 e 525 a. C., se dão como exército judaico, e dão a seus compatriotas da Palestina o nome de judeus (25). A existência posterior da Judéia como distrito à parte do reino dos Ptolomeus e dos Selêucidas, é atestada por José e outras fontes (26).

299. - O templo de Jerusalém, que se tornaria sede da atividade dos escribas e fariseus, fazia da Judéia o centro da cultura espiritual e religiosa do povo judaico disperso pelo mundo afora, e a reação nacional, religiosa e política, iniciada na Judéia pelos Macabeus contra a helenização forçada do país, imposta por Antíoco IV (n. 6-8), dela faria o centro político da Palestina tôda, como o fôra antes. Este movimento, desencadeado pelo sacerdote Matatias em 165 a. C., resultou não sòmente na independência da nação judaica por quase um século (de Matatias a Pompeu: 165-63 a. C.), mas ainda na conquista de distritos que haviam pertencido anteriormente ao reino cismático de Israel, como Jericó, a Samaria e a Galiléia, e no alargamento dos confins da Judéia em sentido próprio, como a haviam deixado Esdras e Neemias e seus sucessores (27). Eiste alargamento se operou, em parte, pela incorporação definitiva de distritos pertencentes a outras províncias da Palestina dos Selêucidas, em parte, pela reconquista de territórios que haviam pertencido ao anterior reino de Judá. Assim temos, por exemplo, a conquista de Gezer por parte de Judas e de Simão (n. 290), enquanto Jonatã obteve dos Selêucidas as torparquias samaritanas de Aphairema, Ramathaim, Lydda e Akrábata, como obtivera antes a cessão da cidade filistéia de Accaron (n. 289) (28). Vimos que os chefes romanos sucessivos reconheceram, e, por assim dizer, legalizaram a anexação dêste distritos (n. 288-290).

300. - Os sucessores de Jonatã até Alexandre Janeu (10376 a. C.) empenhar-se-ão na reconquista do sul da Judéia, invadida, depois da destruição de Jerusalém, em 587 a. C., e durante o exílio da Babilônia, pelos filisteus de Ashdod-Azoto a oeste,

\footnotetext{
(25). - Papiro 30, citado em G. Ricciotti 192-194; cf. 1b. 185-20i; R. H. Pfeiffer 169-172; A. Cowley, Aramaic Papyri of the Fifth Century, Oxford 1923; A. van Hoonacker, Unẹ communauté judéo-araméenne à Elephantine, en Egypte, aux VIe et Ve siècles av. J.-C., Lóndon 1914, etc.

(26). - A. 12, 3, $3 \S 129-4,1 \S 159$; Epistola de Aristélas $\S 107$. 115; F.-M. Abel, Géographie 2, $131^{5}$; id., Marisa dans le papyrus 76 de Zénon, Revue Biblique 33 (1924) 566-574.

(27). - Ver F.-M. Abel, 1b. 120s; M. du Buit, tb. 169.

(26). - F.-M. Abel, 1b. 135. 235s.
} 
e pelos idumeus ao sul. E' possível que os idumeus, que anteriormente ocupavam os territórios entre o Mar Morto e o norte da península do Sinai, o monte de Seir, tenham, por sua vez, cedido à pressão dos árabes nabateus, que avançavam do leste e do sul (29). Em todo o caso, na época de que tratamos, as duas bandas da Iduméia, a oriental e a ocidental (n. 234. 293s), nada mais são do que antigos territórios judaicos, invadidos pelos idumeus, e reconquistados pelos judeus.

301. - Sabemos, com efeito, que Maresa (= Maresha) e Adora (= Adoraim; n. 234), haviam sido fortificados por Roboão, rei de Judá (30), e Hebrón, situada agora na Iduméia oriental (G. 4, 9, 7 § 529-534 e 9 § 554), sempre pertencera à tribo de Judá (Jos. 15, 13; 1 Sam. 30, 26-31; 2 Sam. 2, 1-4). Maresa e Adora foram retomadas por João Hircano (134-104 a. C.), o qual também forçou a judaização dos idumeus (A. 13, 9, $1 \S 257 \mathrm{~s} .15,11$ § 396 ; cf. $12,8 \S 328.8,6 \S 353$; G. $1,2,6 \S 63)$. Daí por diante a Iduméia, seja tôda, seja apenas sua banda oriental (n. 234. 293s), faz parte integral da Judéia, como toparquia única (31). Já mencionamos o fato de os chefes romanos terem reconhecido oficialmente também esta reconquista dos judeus (n. 289). A circunstância dos idumeus participarem do levante que se seguiu à morte de Herodes (G. 2, 3, 1 $\S 43 ;$ A. $17,10,2$ § 254), e da guerra contra Roma (G. $4,4,1$ § 224$6,1 \S 353)$, mostra que a judaização da Iduméia surtira efeito, e que os idumeus se encontravam completamente integrados ao povo judaico (32).

302. - A capital da Judéia, seu ßacíitcov, como a chama José (G. $3,3,5 \S 54)$, a metrópole dos judeus, no dizer de Es-

(29). - Ver 2 Par. 17, 11; 21, 16; 26, 7; Ez. 25, 12-15; 35, 1-15; 1 Mac. 5, 3; 3 Esd. (apócrifo $=1$ Esd. dos Setenta) 4, 50: Edumael relinquant catella quae obtinent Juđaeorum; F.-M. Abel, Géographie 1, 283s: 2, 122s. 148-150; M. du Buit, Jb. 165s. 143s. - Monte de Seir: Dt. 2, 5. 8. 12. 21. 29; Ez. 33, 15, etc. - A Iduméla, tomada por Daví (2 Sam. 8, 14), conseguira novamente llbertar-se debaixo de Jorão (4 Reg. 8, 20-22).

(30). - 2 Par. 11, 80; 14, 9; 20, 37; Mich. 1, 15; F.-M. Abel, 1b. 85. 239. 379.

(31). - E' Incluída como tal na descriçāo da Judéia em G. $3,3,5$ 51-56. José parece distinguir várias Iduméias. Em A. 13, 15, 4 \$96 fala de Adora e Maresa em direção à Iduméia (oriental?), e, além disto, de tôda a Iduméta. Em A./14, 1, $3 \S 10 \mathrm{diz}$ que Antípater, avô de Herodes, fôra nomeado governacor de tôda a Iduméia. Em G. 4, 9, 4 \$ 511 menciona a Iduméla maior, e tb. $9 \$ 552$ fala da Iduméla superior, que parece poder entender-se da parte montanhosa (oriental) da Iduméia, com Hebrón por centro.

(32). - Ver sobretudo A. 13, 9, $1 \S 257 \mathrm{~s}$. Os Idumeus chamam-se de povo conge. nere (G. $4,4,3 \$ 244$ ), parentes e congêneres (ib. $4 \$ 274$. 276. 278), e fala-se do templo e da pátria comum (ib. 4, 4 \& 281 e 5,11 \$11). 
trabão (33), sempre foi, desde os tempos de Daví, Jerusalém, que domina sôbre o próprio território como a cabeça sôbre o curpo (G. ib.), e desempenhava na Judéia, até certo ponto, o papel que cabia à $\pi$ ódıs helenística com relação a seu território (34). Situada no centro da Judéia, conforme diz José, a cidade, não sem motivo, era chamada por alguns, seu umbigo (G. 3, 3, $5 \S 52$ ), enquanto na tradição rabínica ela é o umbigo de todo o mundo (35). O templo de Jerusalém, reconstruído depois do exílio (Esd. 3, 1-13; 5, 1s; 6, 13-18) e inteiramente reformado por Herodes (G. 1, 21, $1 \S 401$ s; A. 15, 11, 1-7), sempre foi o centro religioso dos judeus de todo o mundo, que para lá fielmente mandavam suas contribuições anuais (n. 269), e não raro para lá se dirigiam em peregrinações, vindas de tôdas as partes do Império (36). Este fato fazia da cidade, longe clarissima urbium orientis, non Judaeae modo, no sentido de Plínio, o Velho, a capital espiritual dos judeus dispersos pelo mundo afora (37). Sede, durante algum tempo, de um dos cinco sinédrios ou sínodos de Gabínio (n. 289), era igualmente a capital de um dos onze distritos em que se dividia a Judéia nos tempos do Novo Testamento (G. $3,3,5 \S 55$ ). Como capital da província da Judéia tinha sob seu domínio ainda as cidades de

(33). - Geographica 16, 2, 28 (p. 759); cf. Tácito, Historiarum 5, 8: Hierosolyma genti caput; G. 2, 16, $4 \$ 400$ e 17, 4 \$ 421; mêtrópolis.

(34). - E. Schürer 3, 161; F.-M. Abel, Géographie 2, 152; H. St. Thackeray 7, 485. Em A. 14, 4, $4 \S 74 ;$ G. $1,7,6 \S 154$ é Jerusalém que se declara tributária dos romanos. A carta de Cláudio em A. 20, 1, 2 dírige-se aos governantes de Jerusalem, ao conselho, ao povo, e a todos os judeus. Cf. E. Schürer, ib., onde se citam exemplos de cartas análogas dirigidas aos sidônios, efésios, etc. (A. 14, 10, $2 \S 190$ ); V. Ehrenberg-A. H. M. Jones, Doeuments (ver n. 81) 122-137 e 2 Mac. 1, 1. 10. - Jerusalém, cujo nome primitivo parace ter sido Salém (Gen. 14, 17; A. 1, 10, $2 \S 180$ : Sólyma, o que deu Hierosolyma, falsamente interpretada como /Santa Sólyma), cita-se como Urusalim nos textos cuneiformes de el-Amarna. Yebus designa-a como capital dos jebuseus (Jdc. 19, 10s; 1 Par. 11, 4s), passando ela posteriormente a chamar-se de Cidade de Davi (2 Sam. $5,5-9)$. Os arqueólogos mantêm hoje que o lugar primitivo de Jerusalém e de Sión tenha sido na colina de ofel (= colina, Ophlâs G. 2, 17, 9 $\S 448 ; 5,4,2 \S 145 ; 6,6,3 \S 354)$, ao sul da esplanada do templo; F.-M. Abel, Géographie 2, 360-363; K. Galling, Biblisches Reallexikon (Handbuch zum Alten Testament I), Tübingen 1937, 300-303; L. H. VincentA. M. Steve, Jérusalem (ver n. 82) 611-632; C. Watzinger, Denkmäler Palästinas (ver n. 82) 1, 62, etc.

(35). - Ver Livro dos Jubileus 8, 19; babSanhedrin 37a, etc., 'e H. St. J. Thackeray 2, 590s. Na igreja do Slanto Sepulcro mostra-se ainda um bloco de mármore, que representa o umbigo do mundo; B. Meistermann, Guide de Terre Sainte, 3. ed., Paris 1935, 137.

(36). - J. Felten 2, 10s; G. 6, 9, 8 § 421; Jo. 12, 20; Act. 2, 5-11; 6, 9; 21, 17. Sôbre a visita de Filón a Jerusalém ver o $n .41$.

(37). - Plínio, Naturalis Historia 5, 14, 70. Cf. G. $3,2,4 \S 29$ : Antioquia a terceira cidade do orbe romano; J. Felten 2, 360; Estrabāo, Geographica $16,2,5$ (p. 750). 
Iâmnia (n. 66) e de Jafa, que se dão como apêndices da Judéia, por serem as duas cidades do litoral de população prevalentemente judaica (G. 3, 3, $5 \S 56$ ). Desde o advento de Herodes a Judéia pròpriamente dita contava com o acréscimo da Iduméia ocidental (n. 234. 293s), limitando-se, daí em diante, pelo território dos nabateus ao sul, a faixa helenística marítima a oeste, a Samaria ao norte, o Jordão com o Mar Morto a leste (n. 292; G. $3,3,5 \S 51-58$ ). Veremos, com efeito, que as cidades do litoral, excetuando a cidade livre de Ascalão, se distinguiam, dentro dos territórios sujeitos a Herodes, como coisa à parte, da Judéia pròpriamente dita, e dos outros distritos prevalentemente judaicos.

303. - A parte central da Judéia era ocupada pela montanha de Judá (Jos. 11, 21), da altura média de 800-850 m., que se extendia por c. de $70 \mathrm{~km}$. numa largura média de $20 \mathrm{~km}$. até ao sul de Hebrón, perdendo-se depois gradualmente nas alturas de Bersabé, onde se confunde com as colinas de Judá e a planície marítima (38). A oeste, porém, precipita-se num declive bastante abrupto, de $300-400 \mathrm{~m}$. sôbre $3-4 \mathrm{~km}$. de largura, para encontrar-se com as colinas de Judá, que vão perder-se em dois degraus sucessivas, correspondentes a duas faltas geológicas, na planície marítima (39). Esta situação dava à Judéia e à sua capital uma posição bem defendida a oeste, deixando-a aberta a incursões mais fáceis pelo sul e pelo leste (40). Passan-

(38). - F.-M. Abel, Géographie 1, 63; M. du Buit, ib. 70s. A posiçăo da Judéia na montanha de Judá explíca a expressāo: subir a Jerusalém (Mt. 20, $17 \mathrm{~s} ;$ Mc. 10, 32; Lc. 19, 28; 20, 17; Jo. 2, 13, etc.), e o fato de se dar à Judéla, ou, então, à sua parte central, o nome de oriné $=$ a montanhosa (Jdt. 5, 3. 5. 15 (23). 19 (28); Lc. 1, 39. 65; Protoevangelho de São Tiago, c. 22, 3; Plínio, Naturalis Historia 5, 14, 70). O monte das Oliveiras tem 818 metros de altura, enquanto Jerusalém se situa entre 770 e 737 metros (F.-M. Abel, ib.).

(39). - F.-M. Abel, Géographie 1, 63-65. 371-376; M. du Buit, ib. 70s. As colinas da Judéia são cortadas por vários vales, dos quais notem-se os vales dos Refaim (= Buqueia a so de Jerusalém) e de Soreq (Jdc. 16, 4), por onde passa a estrada de ferro Jerusalém-Tel-Aviv, e o vale dos Terebintos, cena do combate entre Golias e Daví (1 Sam. 17, 1-38; 21, 9).

(40). - M. du Buit, ib. 70. Parece aludir à posição segura da Judéia a expressão: o povo que habita na montanha, etc. (Jdt. 5, 3. 5. 15 [23]. 19 [28]). No tempo dos selêucídas Antíoco $V$ Eupator tenta invadir a Judéia pela Iduméia e Betsur (1 Mac. 6, 31); Apolônio, general de Demé. trio II, aproxima-se vindo de Iâmnia (1 Mac. 10, 69), e o mesmo faz Cendebeu, general de Antíoco VII Sidete (1 Mac. 15, 40). Herodes toma Jafa, passa pela Iduméta até Masada, e sobe até Jerusalém (n. 155s). Numa segunda fase desce da Galiléla para 'Jerić (n. 165), de onde parece ter invadido o restó da Judéia. Vespasiano, por sua vez, ocupa primeiramente a faixa costeira e a Iduméia, e sobe até a Samaria. De lá desce a Jericó (G. 4, 8, 1 § 443-450 e 9, 1 § 486: para invadir !Jerusalém por todos os lados). 
dc a estrada internacional entre o Egito e a Mesopotâmia pela planície do litoral, a Judéia via-se ao mesmo tempo menos exposta às influências estrangeiras, culturais e religiosas (41). Ao norte, na descida do planalto de Benjamim (altura média $750 \mathrm{~m}$.), situado entre a montanha de Judá e a de Efraim (n. 308), a Judéia via-se defendida pelo declive abrupto da subida de Betorón. Situado na estrada de Jerusalém a Jafa e Cesaréia, o desfiladeiro foi o local de inúmeras batalhas no decurso da História (42). Dignas de nota são, ainda, as cidades de Belém, pátria de Daví e de Jesus (1 Sam. 16, 1-13. 18; 17, 58; Mich. 5, 2; Mt. 2, 1-8; Lc. 2, 4-15) (43), e de Hebrón, a cidade dos patriarcas (Gen. 23, 1-20; 25, 9s; 35, 27-29; 50, 12) (44).

304. - Entre a montanha de Judá e a fossa jordânica estende-se o deserto da Judéia (Jdc. 1, 16; Jos. 15, 61; Ps. 63 [62], 1; Mt. 3, 1; Mc. 1, 4; Lc. 3, 2), famoso na história de Daví (1 Sam. $21,1-26,25)$. Segue paralelamente à montanha de Judá, e é entrecortado por vales, que se tornaram célebres na História: o wadi Qilt, por onde passava a estrada antiga de Jericó a Jerusalém (Lc. 20, 30s), o wadi Qumran, célebre pelos rolos do Mar Morto, o wadi en-Nar, continuação do vale do Cedrón (Ez. 47, 1-12), e o wadi Murabaat, um dos refúgios de Simão Bar Kochba (45). Além disto, a Judéia compreende ainda grande parte

(41). - Esta estrada identifica-se, em geral, com a estrada do mar de Is. 8, 23 (9, 1); F.-M. Abel, Géographie 2, 103. 217-219; M. du Buit, 1b. 111 . 157. Duvida D. Baly, Geography (ver n. 85) 113.

(42). - o desflladeiro fíca entre a Betorón superior (Beit Ur el-Foqa; $617 \mathrm{~m}$.), e a inferior (Beit Ur et-Tahta; $400 \mathrm{~m}$.; F.-M. Abel, Géographie 2, 274s; M. du Buit, ib. 189: 640 , respectivamente $460 \mathrm{~m}$.), que distam entre si apenas de 3 a 4 quilômetros. A subida de Betorón, por onde passavam quase todos os exércitos que invadiam a Judéia, pode ser chamado o calcanhar de Aquiles das defesas judaicas (D. Baly, 1b. 21). A configuração do terreno explica !porque sempre ganham os que se acham do lado de cima: Josué contra os reis cananeus (Jos. 10, 10s); Judas Macabeu contra os generais Serón, Lísias, Nicanor (1 Mac. 3, 16. 24; 4, 29; 7, 39); Simão bar Giora contra Céstio Galo e a legiāo XII fulminata em 66 d. C. '(G. $2,19,1 \S 516.2$ 2 521 e 8 546-550); a legiảo árabe contra as fôrças israelís em 1948 (D. Baly, 'lb. 145s).

(43). - F.-M. Abel, Géographie 2, 276.

(44). - Ib. 345s. Hebrón foi ainda a primeira capital de Daví, 2 Sam. 2, 14; 5, 1-5. Sôbre Hebrón como parte da Iduméla ver o n: 301 . Uma estrada de norte a sul - o eixo norte-sul, ou estrada dos santuários - ligava Beisan-Siquém-Betel-Jerusalém-Belém-Mambré-Hebrón-Bersabé; F.-M. Abel, ib. 2, 220; M. du Buit, ib. 96 .

(45). - F.-M. Abel, ib. 1, 104-106. 436. 2, 221: 227; M. du Buit, ib. 71-73; J. T. Mi11k, Dix ans de découvertes dans le désert de Juda, Paris 1957, 16. - 0 deserto de Judá é o local tradicional do jejum de quarenta dias de Jesus, Mt. 4, 1; Mc. 1, 12; Lc. 4, 1s. Mais exatamente indica-se o djebel Qarantal, que domina Jerić a oeste (c. de $500 \mathrm{~m}$. sôbre a planície jordânica), onde se procura também a fortaleza de Dok - Dagôn -1 Mac. 16, 5; A. 13, 8, 
da fossa jordânica, a maior depressão do orbe terráqüeo, desde o wadi Fara com a fortaleza de Alexandrium, até ao Mar Morto. Na parte ocidental, de c. de $10 \mathrm{~km}$. de largura (o ghor ocidental) o vale do Jordão, que no wadi Fara já se acha a 300 $\mathrm{m}$. abaixo do nível do mar, desce até $392 \mathrm{~m}$., na altura do Mar Morto (= bahr Lut, mar do Sal, Gen. 14, 3), o qual, por sua vez, tem a profundidade de c. de $400 \mathrm{~m}$. (46). Dado o clima tropical da fossa jordânica, a região continha vários oasis, como Jericó $(-258 \mathrm{~m}$.), o distrito mais rendoso dos territórios de Herodes (n. 189), Fasaelis (khirbet Fasail; - $250 \mathrm{~m}$.), fundada pelo mesmo Herodes (n. 319), Arquelais, fundada por Herodes Arquelau (47). Nas bordas do Mar Morto encontrava-se a cidadezinha de Engadí, conhecida pela história de Daví (Jos. 15, 62; 1 Sam. $24,1 \mathrm{~s}$, etc.). Também os vaus do Jordão desempenharam seu papel na História (48).

$1 \S 230$; F.-M. Abel, Géographie 1, 373-375. 2, 307; G. M. Perella, I luogh1 santi, Piacenza 1936, 112-116; G. Dalman, Orte- und Wege Jesu, 3. ed., Gütersloh 1924, 99-107. - Ver a descrição das vizinhanças de Jericó em G. $4,8,2 \S 451-458$.

(46). - F.-M. Abel, Géographie 1, 8-11. 79-81. 161-169. 474-483; M. du Buit, ib. 23s. - O Jordão tem uma largura média de 25 metros por 2-3 metros de profundidade. Seu percurso entre o lago de Genezaré e o mar Morto é de 109 $\mathrm{km}$. em linha reta, mas de $320 \mathrm{~km}$. na realidade, devido aos inúmeros meandros que forma. o deserto que ladeía o Jordão de ambos os lados é chamado o ghôr, enquanto a faixa verde de vegetação que o acompanha, é o zôr. Ver também Tácito, Historiarum 5, 6: Nec Jordanes pelago accipitur, sed unum atque alterum lacum integer perfluit tertio retinetur. - O mar Morto, de $85 \mathrm{~km}$. de comprido por 15,7 de lárgo não tem saída. $O$ afluxo de águas do Jordão e outros afluentes $\left(200 \mathrm{~m}^{3}\right.$ por segundo) evapora-se, conservando o lago sua superficie habitual. Este fenômeno faz com que seu conteúdo de elementos salinos seja seis vêzes superior às águas do oceano (de 20-26\%). Já os antigos cantavam as maravilhas dêste lago, a quem chamavam de lago do Asfalto; Tácito, ib.; Éstrabāo, Geographica 16, 2, 42 (n. 763s); Plínio, Naturalis Historia 5, 16, 72 , etc. Ver também G. $4,8,4 \S 476-485$ onde se narra que Vespasiano mandou deitar às águas do mar Morto pessoas manietadas, que nāo sabiam nadar. Teriam ficado boiando.

(47). - F.-M. Abel, Géographie 2, 357-360. 408s. 249; K. Galling, Reallexikon (ver n. 82) 290-297; C. Watzinger, Denkmäler (ver n. 82) 55-57; M. Wheeler, The Walls of Jericho, London 1959; G. Lankester Harding, The Antiquities of Jordan, London 1959, 164-174. Sôbre o clima de Jericó G. 4, 8, $3 \S 473$.

(48). - O mais famoso é o de Adamah ( = tell ed-Damiye), perto da confluência do Yabboq, onde pararam as águas do Jordão em tempos de Josué (Jos. 3, 16). O mesmo fenómeno produziu-se, pela queda de barrancos, em 1267, parando as águas do rio por dez horas, em 1906 e em 1927; cf. J. Garstang, The Foundations of Bible History. Joshua-Judges, London 1931, 237; F.-M. Abel, Géographie 1, 481. - o vau de Goraniye, perto de Jericó (2 Sam. 17, 22; 19, 17s, etc.), está hoje substituído pela ponte de Allenby. Mais ao norte, em Qasr el-Yehud, mostra-se. o lugar tradicional do batísmo de Jesus; F.-M. Abel, ib. 482s; G. M. Perella, ib. 100-111. Ver alnda F.-M. Abel, Exploration de la vallée du Jourdain. Revue Biblique, N. S. 7 (1910) 532-556; 8 (1911) 408-436; 9 (1912) 402-423; 10 (1913) 218-243. 


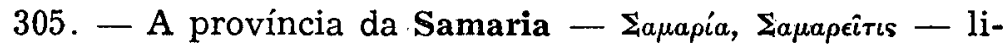
mítrofe com a Judéia ao sul e a leste (nn. 112. 302), fôra o centro político e religioso do anterior reino de Israel, constituído pelas dez tribos de Israel, que se separaram do reino unido depois da morte de Salomão (49). Nos tempos de Herodes e do Novo Testamento representava o que ficara daquele reino depois de passar pela dominação assíria, babilônica, persa e grega (dos Ptolomeus e dos Selêucidas), e a dos macabeus e hasmoneus (50). Nela se encontravam as capitais sucessivas de Siquém (3 Reg. 12, 25), Tirça (ib. 14. 17), e Samaria (ib. 16, 24). Esta última, fundada em posição central e estratégica pelo rei Omri (884-873 a. C.), deu o nome à posterior província (51) . Para consumar a separação política, Jeroboão I (929-920 a. C.) promoveu ainda o cisma religioso, instituindo os santuários de Dan, na Galiléia (tell el-Qadi perto de Banyas), e de Betel, na Samaria ( = Beitin) (52) . Nesta parte do reino, além de Betel (Gen. 28, 19; 12, 8; 13, 3; 33, 1-15) veneravam-se ainda outros lugares famosos na história dos patriarcas e na história posterior, como Siquém (Gen. 12, 6; 33, 18s), e Silo (Jos. 18, 1.8-10; 1 Sam. 1,3) na Samaria, e Fanuel, além do Jordão (Gen. 32, 30) (53). Também Jericó, cidade da tribo de Benjamim (Jos. 16, 1. 7; 18, 12), foi anexada ao reino do norte (3 Reg. 15, 16- 22; 16, 34), sendo novamente repovoada por judeus depois do exílio (Neh. 3,2 ).

306. - Após a tomada de Samaria pelos assírios, em 722 a. C., muitos dos habitantes do reino de Israel foram deportados e substituídos por colonos de várias procedências, entre os quais habitantes de Cutá na Babilônia (4 Reg. 17, 24. 30). Daí o nome de cuteus - Xovraîo - dado por José e os judeus em geral aos habitantes da região (54). À mistura de raças e povos veio juntar-se logo a mistura de cultos e religiōes (4 Reg. 17, 2541 ), e ambas foram a causa da tradicional inimizade entre judeus e samaritanos, que se originou logo depois da volta dos judeus da Babilônia. Repelidos pelos judeus (Esd. 4, 1-3; Neh.

(49). - 3 Reg. 12, 1-24; 2 Par. 10, 1-11, 4; F.-M. Abel, Géographie 2, 93-97; M. du Buit, ib. 154-157.

(50). - Ver G. 3, 3, 4 \$ 48-50: F.-M. Abel, ib. 2, 93-97; royaume d'Israël. 104: sous les Assyriens. 120: sous les Perses. 134s: sous les Séleucides. 153s; $M$. du Buit, ib. 66-69. 154-157.

(51). - F.-M. Abel, ib. 2, 458-460. 485, 443-446

(52). -3 Reg. 12, 28s; F.-M. Abel, ib. 2, 270s. 302

(53). - F.-M. Abel, ib. 2, 406, 458-460. 462s.

(54). - A. 9, 14, 3 \$ $288-291 ; 11,4,4 \S 88$ e $7,2 \S 302 ;$ G. $1,2,6 \S 63 ;$ E. Schürer $3,6^{143}$. 
$2,20)$, e tendo em vão procurado impedir a reconstrução de Jerusalém e do templo (Esd. 4, 4-22; Neh. 2, 20; 4, 1-3. 7-15; 6, 1-9) (55), os samaritanos continuaram em seu cisma religioso, construindo um santuário próprio no tradicional monte de Garizim (Dt. 11, 29; 27, 12; Jos. 8, 33; Jdc. 9, 7), obtendo mais tarde de Antíoco IV que êste mesmo templo fôsse dedicado a Zeus Xênios ou Júpiter Hospitalis (56). Esta situação devia forçosamente expor os samaritanos às represálias dos macabeus e hasmoneus. Jonatã conseguiu obter dos selêucidas a cessão de quatro distritos da Samaria e de Accaron, cessão respeitada pelos romanos (n. 290). João Hircano tomou Siquém, destruiu o templo do Garizim, e, mais tarde, a própria Samaria, anexada com seu distrito à Judéia (57).

307. - Libertada por Pompeu, a cidade é reconstruída por Gabínio (n. 286s). Administrada por Herodes debaixo de Sexto César (nn. 108. 261), é concedida a êle, já como rei, por Marco Antônio, mediante o pagamento de um tributo (n. 234), e, livre de tributos, por Otaviano (n. 294). A mistura de raças e religióes terá sido a causa porque os samaritanos fàcilmente a êle se submeteram (n. 295). Ele, por sua vez, respeitou e favoreceu seu sincretismo religioso, e suas tendências helenísticas, construindo em Samaria-Sebasté um templo dedicado a Augusto (n. 262), e respeitando, até certo ponto, o regime helenístico do distrito. Durante seu govêrno não se mencionam atritos entre judeus e samaritanos (n. 287), mas os vestígios da tradicional inimizade reaparecem no Novo Testamento, e, mais ainda, em José, que nos informa sôbre vários incidentes que se deram debaixo dos procuradores romanos e de Agripa I (58) .

(55). - F.-M. Abel, ib. 2, 104; G. Ricciotti 136-143. 175-183.

(56). - 1 Mac. 3,$10 ; 2$ Mac. 6,$2 ;$ A. $12,5,5 \S 257-264 ; 13,9,1 \S 256 ; 11,8,2 \S 306-$ 312 e 4 \$22-324; cf. Jo. 4, 9. 20; F.-M. Abel, 1b. 1, 360-370. Ver em G. Ricciotti 182 uma moeda de Antonino Pio com a representação do templo.

(57). - A. $13,9,1 \S 255$ s e 10, 2 \$ $275-3 \S 283,15,4 \S 396 ;$ G. $1,2,6 \S 63$.

(58). - Ver Eccll 50, 28: $O$ povo insensato que habita em Siquém; Lc. 9, 52s; 10,$33 ; 17,16$; Jo. 4 9: Os judeus nāo se dão com os samaritanos; 8, 48, etc. Sôbre as tropàs sebastenas no julgamento de Jesus ver o n. 275; debaixo de Agripa I A. 19, 9, 1 \$356-359 e $2 \S 361$. 364-366. Os samaritanos mantiveram-se neutros durante os distúrbios que se seguiram a morte de Herodes, G. $2,6,3 \S 96 ;$ A. $17,11,4 \S 319$, e durante a guerra de 66-70 d. C. Sôbre desavenças entre Pôncio Pilatos e os samaritanos A. 18, 4, 1 § 85-87; entre os judeus e samaritanos debaixo de Cumano A. 20, 6, 1 $\$ 118-3 \$ 136$ - G. $2,12,5 \$ 236-7 \$ 246$. Ver também H. L. Strack-P. Billerbeck 1, 538-560; $\mathrm{E}$. Sichtirer 3, 6-8. Sôbre os samaritanos de hoje, sua religlão, seus costumes, etc., ver G. Ricclotti 179; M. Gaster, The Samaritans: Their History, Doctrines and Literature, London 1925; J. A. Montgomery, The Samaritans. The Earliest Jewist Sect. Their History, Theolozy 
308. - Nos tempos de Herodes e do Novo Testamento a Samaria limitava-se, ao sul pela Judéia; a oeste, pelos territórios de Antípatris, Narbata e Cesaréia, e o monte Carmelo; ao norte, pela Galiléia inferior e a Baixada Grande de Esdrelón, e o território de Citópolis (= Beisan); a oeste, pela fossa jordânica (n. 304) (59). Ao contrário da Judéia (n. 303), a Samaria está situada numa região fisicamente menos abrupta, excetuando o lado oriental, limitado pelo declive da fossa jordânica, enquanto a oeste e norte é fàcilmente acessível a incursões inimigas e a influências culturais. Junto dela passava a estrada comercial do Egito a Damasco, e a cidade de $\mathrm{Me}$ guido (= tell el-Mutessellim) foi o lugar clássico de muitas katalhas (60). Os montes da Samaria dividem-se em dois maciços, a montanha de Manassés, com os montes de Gelboé (altura média entre 300 e 500 m.; 1 Sam. 28. 4; 31, 1-13; 2 Sam. 1, 1-27), o Garizim ( $868 \mathrm{~m}$.) e o Ebal (938 m.), e a montanha de Efraím (Jos. 17, 15s. 18), ou montanha de Israel (Jos. 11, 21) (61). José realça a fertilidade da Samaria, o que explica a densidade de sua população (G. $3,3,4 \S 49$ s).

309. - A província da Galiléia limitava-se nos tempos do Novo Testamento, a oeste, pelo território de Ptolemaide-Acco, e o monte Carmelo, então em mãos dos tírios (G. 3, 3, 1 § 35); ao sul, pelos territórios da Samaria e de Citópolis (= Beisan); a leste, pelo Jordão e os lagos de Genesaré e de Hulé; ao norte,

and Literature, Philadelphia 1907; J. Jeremias, Samáreia, etc., Theologisches Wörterbuch zum Neuen Testament VII, Stuttgart 1960, 88-94; A. Ishak, The History and Religion of the Samaritans, Jerusalém s. a.

(59). - G. 3, 3, $4 \S 48-50$; F.-M. Abel, Géographie 2, 153s; M. du Buit, ib. 174; A. Alt, Zur Geschichte der Grenze zwischen Judäa und Samaria, Palästina. Jahrbuch 31 (1935) 94-111; L. Häfeli, Samaria und Peräa bei Flavius Josephus (Biblische Studien, 18. Band, 5. Heft), Freiburg 1. Br. 1913.

(60). - Ver M. du Buit, ib. 70. Sôbre as estradas F.-M. Abel, Géographie 2, 218s. 220. Escavaçōes realizađas em Samaria-Sebasté revelaram a influência egfpcia. Ver os famosos relevos de marfim (ver Am. 5, 12; 6, 4) em $K$. Galling, Reallexikon (ver n. 82) 149; C. Watzinger, Denkmäler (ver $n$. 82) 1, 112-114 e Tafel 37; A. Reifenberg, Ancient Hebrew Arts, New York 1950, 25-29; A. Parrot, Samarie capitale du royaume d'Israël (Cahiers d'Archéologie Biblique 7, Neuchâtel/Paris 1955, 46-53. Sôbre os óstracos encontrados na Samaria ver A. Parrot, ib. 54-61; K. Galling, ib. 407-409. - De entre as batalhas que se realizaram perto de Meguido tornou-se famosa a de Tutmosis III contra os príncipes aliados asiáticos (F. Bilabel, Geschichte Vorderasiens und Agyptens vom 16.-11. Jahrhundert, Heidelberg 1927, 32-38), e, mais tarde, a de Lord Allenby contra os turcos em 1918, que lhe valeu o título de Viscount of Megiddo (Encyclopaedia Britannica I, Chicago/London 1952, 649). Ver também Jdc. 4, 1-5, 32 (Sísera, Débora e Baraque); 4 Reg. 9, 27 (Ocoziàs de Israel); 4 Reg. 23, 29s; 2 Par. 35, 22 (Josias de Judá). Sôbre Armaguedon de Apc 16, 16 e Meguido ver E.B. Allo, Saint Jean. L'Apocalypse, Paris 1921, 239s.

(61). - F.-M. Abel, Géographie 1, 62s. 358-360. 2, 360-370; M. du Buit, ib. 66-68. 
pelo território de Cádasa, sujeito aos tírios (62). Parte do anterior reino de Israel (4 Reg. 15, 29), a Galiléia não figura na linguagem administrativa dos Selêucidas, e parece que seu território estava dividido entre as cidades fenícias do litoral, e as do interior (63), ou, então, anexado, em parte, à Samaria (64). Libertada pelos macabeus e hasmoneus, a Galiléia foi transformada em um único sínodo ou sinédrio por Gabínio, com a capital em Séforis (n. 289). Passou, em seguida, às mãos de Herodes (nn. 159. 291). Apesar de ter feito parte do reino de Israel, e não obstante ter incluído em seus limites o santuário cismático de Dan (n. 305), a Galiléia não chegou a participar do cisma religioso da Samaria, como se poderia supor diante da história comum das duas províncias. Parte ao menos da Galiléia mostrou-se hostil inicialmente ao movimento dos macabeus (1 Mac. 5, 14s), mas já em tempos de Herodes a Galiléia opôs resistência violenta ao novo regime, e vemos pela história do Novo Testamento e pela narração de José que ela se achava perfeitamente judaizada, colaborando intensamente na guerra contra Roma. Se a literatura rabínica nota diferenças entre galileus e judeus, não afirma que os primeiros não fôssem judeus autênticos. Talvez se possa mesmo supor que durante a época da dominação persa houvesse relações entre a Galiléia e a Judéia, preparando a absorção da primeira pela segunda (65).

(62). - Kádasa ou Kùdasos é a Qadesh de Neftalí (Jos. 12, 22; 19, 37; 20, 7; 1 Mac. 11, 63. 73); ver A. 13, 5, 6 \$ 154; G. 2, 18, 1 \& 459; 3, 3, 1 s 35-38; 4, $2,3 \S 105$. O nome de Galil ou Guelilah (= distrito) já aparece em Jos. 20, 7: 3 Reg. 9, 11; 4 Reg. 15, 19. Em Is. 8, 23 (Vg. 9, 1) fala-se na Galiléia dos gentios (cf. 1 Mac. 5 . 15; Mt. 4, 15), o que se explica, em geral, da preponderância dos gentios nesta região; H. L. Strack-P. Billerbeck 1, 153 . Ver também F.-M. Abel, ib. 2, 154. 416; M. du Butt, ib. 60-65. 173. - Sôbre o lago de Genezaré (Lc. 5, 1), ou mar da Galiléia (Mt. 4, 18; 15, 29; Mc. 1,$16 ; 7,31$ ), ou mar de Tiberíades (Jo. 6,$1 ; G .3,3,5$ \& 57 ), etc. ver nota 117 da Introđução e F.-M. Abel, ib. 1, 494-498. Sôbre o lago de Hulé ver o n. 327.

(63). - Cêrca de 164 a. C. a Galiléla é nomeada, juntamente com Ptolemaide, Tiro e Sidón, como hostil para com os judeus daquelas regiōes (1 Mac. 5, 14s), - que provocou a reação de Judas Macabeu, que para lá enviou a Simão (ib. 17. 20-23. 35), Este deu várias batalhas na Galiléia aos povos que foram vencidos e perseguidos até às portas de Ptolemaide (ib. 21s). Simão, por conseguinte, combate os diversos povos que dominavam na Galilélia, e não um general do rei, F.-M. Abel, ib. 2, 134; td., Maccabées 94; ver A. 12, 8, 1 \$31 - 2 \&344. Do mesmo modo Cádasa, sujeita aos tírios, podia ser chamada de cidade da Gallléla, 1 Mac. 11, 63.

(64). - Demétrio I, ao conceder a Jonatã os distritos de Aphairema, Lydda e Ramathaim (n. 290) diz que os mesmos foram desmembrados da Samaria e da Galiléia (1 Mac. 10,30), enquanto Demétrio II menciona apenas a Samaria (ib. 11, 34.

(65). - Ver E. Schürer 3, 3s; J. Klausner, Jesus von Nazareth, 3. ed., Jerusalém 1952, 317; H. L. Strack-P. Billerbeck 1, 156-159. 
310. - A Galiléia dividia-se em duas, a superior e a inferior (G. $2,20,3 \S 573 ; 3,3,1 \S 35.38 \mathrm{~s} ;$ V. $37 \S 187 \mathrm{~s} .12 \S 67$ ),

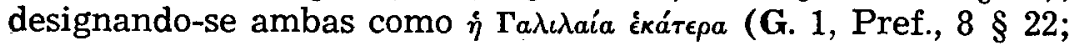

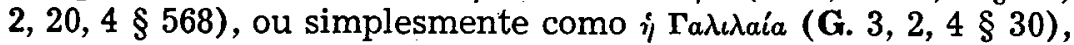

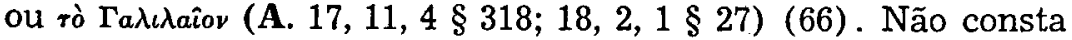
se ambas formavam duas divisões administrativas diversas, ou apenas se referiam a divisões geográficas, que coincidem, em grande parte, com a descrição de José (G. $3,3,1 \S 35-2 \S 43$ ). A Galiléia superior, pràticamente restringida à parte montanhosa da região, limitava-se a leste pelo curso superior do Jordão e o lago de Hulé (n. 327), confinando com a Gaulanítide superior (n. 322) e o distrito de Ulata (n. 327); ao norte e a oeste com o território de Tiro; ao sul com a Galiléia inferior, que se limitava, por sua vez, por uma linha que passava do Jordão por Corozain (Chorazin $=$ Keraze), a $3 \mathrm{~km}$. ao norte do lago de Genesaré, Yaquq e Bersabé (= Abu esh-Sheba) (67).

311. - Na Galiléia superior encontram-se o djebel Djermaq (1.208 m.), o ponto mais elevado da Palestina, e o djebel Kanaan $(955 \mathrm{~m}$.), em cujas encostas está situada a cidade de Safed, a mais alta da Palestina $(850 \mathrm{~m}$.), e um dos mais famosos centros de estudos rabínicos (68). Notem-se, ainda, as cidades de Corozain (Mt. 11, 20-23; Lc. 10, 13) e de Giscala (Gischala = el-Djish), pátria de João, filho de Leví, um dos chefes mais famosos durante a guerra de 66-70 d. C., e inimigo de José durante o seu govêrno da Galiléia (V. $10 \S 43-45.13$ \$ 7076, etc.; G. $2,20,6 \S 575.21,1 \S 585-2 \S 594$, etc.) (69). A Galiléia inferior tinha por limite ocidental o território de Ptolemaide-Acco, anexo à província da Síria, e por limite oriental o lago de Genesaré e o curso do Jordão entre o mesmo lago e o território de Citópolis (= Beisan). Era um distrito de planícies, planaltos e colinas. Seus pontos mais elevados são o monte Tabor (djebel et-Tor, $562 \mathrm{~m}$.), e o Nebi Dahi ( $515 \mathrm{~m}$.), abusivamente chamado o Pequeno Hermón (70). A cidade mais forte

(66). - Ver as duas Galilélas também em M. Shebilth 9, 2; palSanhedrin 1, 18d; Tos. Sanhedrin 2, 6, etc.

(67). - F.-M. Abel, Géographie 2, 154. 299; M. du Buit, ib. 60. 173.

(68). - F.-M. Abel, 1b. 59s. 2, 456. 154; M. du Buit, ib. 60 .

(69). - Uma tradição antiga fazla de Giscala a terra de origem da familia de São Paulo. Ver S. Jerônimo De Viris nlustribus, c. 5 (PL 23, 646B); Commentarius in Epistolam ad Philemonem, v. 23s (PL 26, 653D). Sôbre Corozaln e Giscala ver F.-M. Abel, tb. 2, 299.338.

(70). - F.-M. Abel, ib. 60s; M. du Buit, ib. 61-64. A confusão com o Hermón provém da proximtade do Nebi Dahi junto do monte Tabor e da menção dêste e do Hermón em Ps. 88 (89), 13; ver Ps. 41 (42), 7. 
da Galiléia inferior, e, ao mesmo tempo, de tôda a Galiléia, era Séforis (= Saffuriya, a $9 \mathrm{~km}$. a NO de Nazaré), a futura Diocesaréia, cidade mencionada pela primeira vez na época de Alexandre Janeu (A. 13, 12, 5 § 338). Gabínio fêz dela a capital do sínodo ou sinédrio da Galiléia (n. 289); Herodes a tomou e a fortificou (n. 159). Destruída por Quintílio Varo, governador da Síria, em 4 a. C., foi reconstruída por Herodes Antipas, que dela fêz a capital de sua tetrarquia (A. 18, 2, $1 \S 27$ ) (71). A Galiléia inferior tem interêsse especial para os cristãos, como uma das regiões principais da atividade de Jesus. Nela, com efeito, situam-se as cidades e vilas de Nazaré, Caná, Naim, Cafarnaum, Mágdala, etc. (72), e nela Herodes Antipas fundará a cidade de Tiberíades, nas bordas do mar da Galiléia (A. 18, 2, 3 $\S 36-38$ ). Esta cidade, com as de Tariquéia e Jotapata (n. 45), desempenhará papel importante na vida de Flávio José. Ambas as Galiléias, intensamente populosas (G. $3,3,1 \S 43 ;$ V. 45 § 235), e refúgio habitual de bandidos políticos, foram o território de muita atividade policial de Herodes (nn. 102. 105. 155. 159. 161. 164) (73).

312. - Parece que a Grande Planície de Esdrelón (Jdt. 1, 8), ou Baixada Grande, que se estende entre o monte Tabor e o Carmelo, as colinas da Galiléia inferior e as da Samaria, formava um distrito administrativo próprio (74). Restituída por Júlio César a Hircano II, parece ter feito parte dos domínios da

(71). - F.-M. Abel, 1b. 2, 305s; A. 17, 10, 5 § 271.

(72). - F.-M. Abel, ib| 2, 395, 412s. 292s. 373; G. M. Perella, I luoghi santi, Piacenza 1936, 40-44. 119-127. 138-144. - Em Jo. 12, 21 menciona-se a cidade de Bethsaida da Galiléta, pátría do Apóstolo Filipe. Cf. 1, 44: pátria de Filipe, de André e de Pedro. Procura-se a cldade na margem oriental do lago de Genesaré, F.-M. Abel, ib. 2, 279s; G. M. Perella, ib. 164-175. o tetraca Filfpe a transformou em polls e chamou-a Bethsaida Julias, em honra da filha de Augusto, G. 2, 9, 1 168; 3, 10, 7 515; A. 18, 2, 1 \$ 28. Conforme a prineira passagem de $G$. a ctdade ficava na Gaulanitide inferio, mas conforme G. $3,3,1 \$ 37$ parece que a Galiléia podia incluir Hipos e Gádara, e até a Gaulanítide, G. 220,4 \& 568 . O Talmud e o geógrafo Ptolomeu, Geographia 5, 15, 3, classiftcam Bethsaida Julias como cidade da Galiléia, G. M. Perella, ib. 168. O lago de Genesaré (Lc. 5, 1) era chamado mais frequientemente de lago da Galiléia (Mt. 4, 18; 15, 29; Mc. 1, $16 ; 7,31 ;$ Jo. 6,1$)$, apesar do fato de a banda oriental do mesmo não fazer parte da Galléla pròpriamente dita. Trata-se, pois, de Galiléia em sentido mais amplo.

(73). - Ver Estrabão, Geographica 16, 2, 37 (p. 761), conforme o qual o banditismo na Palestina fol consequiência das tiranias pelo que confirma o que dissemos sôbre o banditismo político no $n$. 105 .

(74). - F.-M. Abel, Géographle 1, 91s. 411-413, e mapa IX; M. du Buit, ib. 64s; G. $2,12,3 \S 232 ; 3,3,1 \$ 38$ e $4 \$ 48$. A Baixada Grande (1 Mac. 12, 49) tem seu nome da cidade de Yizreel $(=$ Zerin), residêncla de Acab, etc. (Jos. 19,$18 ; 3$ Reg. 18,$45 ; 21,1.23$, etc.). Na literatura posterior aparecem as formas Esdrelon, Esdrelom, Esdraelon Stradela, etc. Em hebratco chama-se simplesmente Emeq $=$ vale,, planicle. 
corôa (A. $14,10,6 \S 207$ ), e vemos que os descendentes de Herodes têm interêsse especial nesta região (75) . Durante a guerra contra Roma são os veteranos de Gaba, colônia militar fundada por Herodes (G. 3, 3, $1 \S 36$ ), que se encarregam da defesa desta mesma Baixada (V. 24 \& 115-119). Planície de $75 \mathrm{~m}$. de altura média, era ela o lugar ideal para as invasões da Palestina pelo norte, e a sua extensão de cêrca de $250 \mathrm{~km}^{2}$ fazia dela um dos campos de batalha preferidos pelos antigos (76) .

313. - A última província judaica pròpriamente dita, a de menor importância política e econômica, era a Peréia, nome que designa exclusivamente 0 território judaico de Além-Jordão (77). O têrmo חєeaía, a Peraea de Plínio, o Velho (78), é apenas

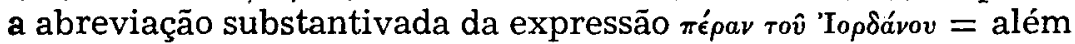
do Jordão, que é, por sua vez, tradução literal do hebraico Ever ha-yarden de Is. 8, 23 (Vg. 9, 1) (78a). Nos tempos do Novo Testamento a província limitava-se ao norte pelo território de Pela, cidade da Decápole; a oeste, pelo Jordão; ao sul, pelo território dos nabateus, limítrofes com a fortaleza de Maqueros e seu distrito; a leste, pelos territórios de Filadélfia (= Ammân) e Gérasa, ambas da Decápole (G. 3, 3, 3 § 47) (79). Sua capi-

(75). - José com suas tropas assalta a vila de Besara, nas fronteiras de Ptolemaide-Acco, e dela tíra o trigo pertencente a Berenice, irmã de Agripa II (V. $24 \S 115-119$ ). Alguns jovens galileus, postados como guardas na Baixada Grande, armam uma emboscada à mulher de Ptolomeu, epítropos de Agripa, quando ela, acompanhada de uma escolta de cavalaria se dirige aos domínios reais (V. $26 \S 126 \mathrm{~s})$. Em outra passagem é o próprio Ptolomeu a vítima do assalto (G. 2, 2, 3 §595). A Baixada Grande é mencionada ao lado da Galiléía em 1 Mac. 12, 49 .

(76). - Além das batalhas menclonadas na nota 60 dêste capítulo, veja-se ainda a batalha de Napoleão e do general Kléber contra os turcos em 1799, e E.-J. Finbert, Israël (Les Guides Bleus), Paris 1955, 232: Les Egyptiens, sous Thoutmès I, II et III, Ramsès II, Séti I, Ménéptah, les Hyksos, les Canaées, les Mongols les Grecs, les Romains... et les Croisés y versèrent ou y firent verser le sang.

(77). - Em A. 13, 2, $3 \S 50$; G. 2, 12, $3 \S 247$ temos a ordem seguinte: Judéia,'Samaria, Peréia; em G. $3,3,1 \S 35-5 \S 58$ : Galiléia, Peréia, Samaria, Judéla. - Sôbre a Peréta na Mishnah ver $\mathbf{E}$. Schürer $3,2 \mathrm{~s}$.

(78). - Naturalis Historia $5,14,70$.

(78a). - Ver também Jat. 1,9; Mt. 4, 15, 25; Mc. 10 1. Por pleonasmo diz-se em G. 2, 3, 1 43: a Peréia além do Jordảo. - Os habitantes da Peréia podem ser chamados simplesmente perásantes Iordánên potamón, A. 17, 10, 2 § 254. A expressão Além-Jordão (ver Alemtejo) exprime suficientemente a situação geográfica da região, enquanto o têrmo Transjordânia pode implicar um conceito político, e. conotar a região sujeita ao mandato Inglês de 1922 a 1948 , O Reino Hashemita do Jordão, ou Jordânia, parece ter adotado êste nome para significar que reclama para si ambas as margens do Jordão. Comparem-se, ainda, a província persa de Abar nahara (n. 297), onde o rio se refere ao Eufrates, e a Peréia dos Rodios, significando os territórios em terra firme aliados a Rodes; ver Estrabão, Geographica 14, 2 1 (p. 651), e A. H. M. Jones, The Greek City from Alexander to Justinian, Oxford 1940, 44.

(79). - F.-M. Abel, Géographie 2, 154; M. du Buit, ib. 79-82. 
tal era, em tempos de José, Gádara (= tell-Djadûr), situada perto de es-Salt, na estrada de Ammân para Jerusalém (80).

314. - Conforme José a Peréia era deserta e acidentada, mas rica em riachos e fontes (G. $3,3,3 \S 44 \mathrm{~s}$ ) (81). E' cortada em duas partes pelo rio Yabboq (= wadi Zarqa; Gen. 32, 23; Num. 21, 24, etc.), fazendo o distrito setentrional parte do planalto de Irbid (de 500-600 m.), e da montanha de Adjlun (800 m. e mais), assim denominada da vila do mesmo nome (82). $O$ distrito do sul compreende a montanha de es-Salt (20 por $15 \mathrm{~km}$.), e o planalto de Balqa, onde se encontram as cidades de Ammân e Madaba (83). A leste um dos pontos culminantes dêste planalto, situado a pico sôbre a planície jordânica, é o monte Nebo (ras en-Neba, $835 \mathrm{~m}$.), lugar tradicional da morte de Moisés (Dt. 32, 49; 34, 1) (84).

315. - A Peréia compreende, além disto, a faixa oriental da planície jordânica (o ghor oriental), que se estende numa largura de 5 a $12 \mathrm{~km}$., do lago de Genesaré até ao mar Morto (85). Nela encontravam-se as cidades de Betharampta ( = Beith Haram; Jos. 13, 27; Num. 32,36), a posterior Livias (86), e Callirhoé, lugar de fontes termais perto do mar Morto e da forta-

(80). - G. 4, 7, $3 \S 413 s .417 .4 \S 419 s .5 \S 428$; Ptolomeu, Geographica 5, 14, 18: Gadora; Talmud: Gador; ver F.-M. Abel, ib. 2, 174. 324; H. St. J. Thackhray 3, 120s. Deve tratar-se da mesma Gádara em G. 1, 4, 2 86, conquistada por Alexandre Janeu. Escritores anteriores atribuiam a José a confusão com a Gádara da Decápole: E. Schürer 3, 103; U. Holzmeister 180 .

(81). - Plínio, ib. define o pais, seus habitantes e sua posição do modo seguinte: Peraea, asperis dispersa montibus et a caeteris Judaeis Jordane amne discreta:

(82). - F.-M. Abel, Géographie 1, 67s. 378; M. du Buit, ib. 79s.

(83). - Ammân é a antiga Rabbath dos filhos de Amón, capital dos amonitas, conquistada por Davi (2 Sam. 11, 1; 12, 26s, etc.), a Filadélfia dos Ptolomeus; Madaba (Medaba), cidade dos moabitas (Num. 21, 30; Jos. 13, 9. 16; 1 Mac. 9, 36, etc.), tornou-se célebre pelo mapa da Palestina do $s$. V-VI, ver n. 85a e F.-M. Abel, ib. 1, 378-384. 2, 424s. 381s. A Gádara da Peréia e es-Salt faziam parte da Regio Gadara, subdivisão da posterior Palaestina Prima. Es-Salt provém do latino saltus, que designa um território montanhoso e de aproveitamento difícil, em oposição a fundus, F.-M. Abel, ib. 2, 174².

(84). - F.-M. Abel, ib. 1, 379.

(85). - F.-M. Abel, ib. 171-176; M. du Buit, ib. 82 .

(86). - Betharampta é hoje er-Ramé, a $4 \mathrm{~km}$. a oeste de el-Hammam, perto de entrada do Jordão no mar Morto; F.-M. Abel, 1b. 2, 273. 1, 459; Plínio, Naturalis Historia, 13 3, 44; Ptolomeu, Geographia 5, 15, 6. Conforme José, A. 18, 2, $1 \S .27 ;$ G. 2, 9, $1 \S 168$ a cidade passou depois a chamar-se Julias. Duvidam H. St. J. Thackeray 2, 389; U. Holzmeister 71. Parece, com efeito, que José não distingue sempre com exatidão entre esta cldade e Bethsaida Julias (ver nota 72 dêste capítulo). 
leza de Maqueros (87). No planalto de Balqa encontrava-se a cidade e $o$ distrito de Esbus, a Esebonitis, a antiga Hesebon (Heshbon), capital de Sihon, rei dos amorreus (Num. 21, 26; Dt. 1, 4, etc.) (88). Herodes a transformou em colônia militar de veteranos (A. 15, 8, $5 \S 294 ;$ G. $3,3,3 \S 47$ ). Daí o caráter prevalentemente pagão da cidade, que se encontra entre as primeiras cidades saqueadas pelos judeus em 66 d. C. (G. $4,18,1$ § 458) (89).

316. - Tendo a Peréia estado sujeita a prolongado domínio estrangeiro, os judeus começaram a interessar-se novamente por ela de modo ativo a partir das campanhas de Judas Macabeu em Galaad (1 Mac. 5, 3-44) (90). Com a chegada de Pompeu e a libertação das cidades da Decápole, algumas delas anexadas à Judéia por Alexandre Janeu (A. 13, 13, 3 § 356s), a Peréia ficou reduzida aos limites descritos mais acima, e Gabínio dela fêz um único sínodo ou sinédrio, com a capital em Amatûs (n. 289), cidade que cedeu posteriormente seu lugar a Gádara da Peréia (n. 313). Ao mesmo tempo Gabínio legalizava a aquisição desta parte da Transjordânia por parte dos judeus (n. 289). Não se menciona a província durante a campanha de Herodes pela conquista de seu reino, o que nos faz supor que ela não lhe opôs dificuldades especiais, mas se deixou levar passivamente a reconhecer o novo soberano (n. 295). A primeira guerra do rei com os nabateus levou-o à Peréia e aos distritos vizinhos de Filadélfia-Ammân (n. 196). As fortalezas de Maqueros e de Herodium de Além-Jordão, e a colônia militar de Hesebon (n. 315 ), atestam o seu interêsse pela defesa desta parte de seu reino. Em 20 a. C., seu irmão mais novo Feroras será nomeado tetrarca-vassalo da provincia (n. 247-249). A judaização efetiva da mesma é comprovada pela participação de seus habitantes na revolta contra Arquelau (G. 2, 3, $1 \S 43 ;$ A. $17,10,2 \S 254$ ) e na guerra contra Roma (G. $2,20,4 \S 566$ s; $4,7,3 \S 413$ s; e 7 , $6 \S 439$, etc.).

\footnotetext{
(87). - F.-M. Abel, ib. 1, 461; Plínio, Naturalis Historia 5, 16, 72: Calidus fons medicae salubritatis Callirhioè (de kállos = beleza e rhoé = fluente), aquarum gloriam ipso nomine praeferens. - As termas foram refúgio de Herodes em seus últimos dias, A. 17, 6, 5 $\$ 168-173 ;$ G. 1, 33, 5 $\$ 657$.

(88). - F.-M. Abel, ib. 2, 348s.

(89). - Esebon certamente fazia parte do reino de Herodes, e em A. 15, 8, 5 \& 294 é positivamente chamada de cidade da Peréia. Diante disto deverá corrigir-se o mapa IX em F.-M. Abel, ib. 2, apêndice e Histoire 1, 400-401 (Royaume d'Hérode), reproduzido neste volume. Ver o mapa no apéndice de $H$. St. J. Thackeray 2.

(90). - Ver A. 13, $1,2 \S 261.15,1 \S 390.4 \S 395-397 ; 14,1,4 \S 18$ e F.-M. Abel, 1b. 2. 133-137.
} 
317. - II. A expansão do reino de Herodes depois de Augusto. - Tendo examinado os territórios que couberam a Herodes como sucessor de Hircano II (n. 290), e os que lhe foram cedidos por Marco Antônio (n. 291), convém passar em revista as cidades e os distritos que lhe foram confiados por Augusto em três doações sucessivas. Em 30 a. C., restituiram-se-lhe os distritos dados por Marco Antônio a Cleópatra, isto é, Jericó, Gaza e Jafa, Hipos e Gádara (nn. 189. 191. 211), e foram-lhe entregues a Samaria (n. 150), e as cidades marítimas de Antedón e Torre de Estratão (n. 211). Estas duas cidades são as únicas aquisições inteiramente novas de Herodes, que expressamente se nomeiam, e só a primeira menciona-se entre as cidades libertadas por Pompeu, e reconstruídas por Gabínio (n. 285).

318. - Em 24/23 a. C. Herodes recebeu ainda a Traconítide, a Batanéia, e a Auranítide, e em 20 a. C. o território restante, situado entre a Traconítide e a Galiléia, ou sejam os distritos de Panéias e Ulata, com seus arredores (n. 266s). Não se menciona expressamente a Gaulanítide, que consta, todavia, das regiões deixadas pelo rei a seu filho Filipe (A. 17, 8, 1 § 188; $18,4,6 \S 106$; G. $2,12,8 \S 247$ ), e fala-se de sua atividade construtora neste distrito (G. $2,9,1$ \& 168) (91). Sem a Gaulanítide não teria êle tido livre passagem para a Batanéia e os distritos adjacentes, separados como estariam da Galiléia pela Gaulanitide e o território de Citópolis $(=$ Beisan). Por conveniência designamos os territórios herodianos situados entre o lago de Genesaré e o djebel Hauran como territórios nordestinos de Herodes.

319. - Indiretamente temos conhecimento de mais outras cidades helenísticas sujeitas a êle. Deixou êle por testamento as cidades de Azoto, Iâmnia e Fasaelis a sua irmã Salomé (G. 2, 6, $3 \S 98 ;$ A. 17, 8, $1 \S 189$ e 11, $5 \S 321$ ). Fasaelis fôra fundada por êle mesmo (A. 16, 5, $2 \S 144 \mathrm{~s} ; \mathbf{G} .1,21,9 \S 418$ ), enquanto Azoto e Iâmnia figuram entre as cidades libertadas por Pompeu, e reconstruídas por Gabínio (n. 286) . Todavia, não podia o rei têlas deixado a outrem, se não estivessem em seu poder, e não é senão natural supor que as tivesse recebido juntamente com

(91). - F.-M. Abel, ib. 2, 155. Em G. 1, 23, 8 §88 José menciona apenas a Traconitide e os distritos vizinhos, enquanto em $G .2,6,3 \S 95$ fala da Batanéla, da Traconítide, da Auranítide e de certas partes do território de Zenodoro, nas vizinhanças de Panéias (n. 257). Mais tarde inclui-se ainda Gámala (n. 323), a Gaulanfitide, a Batanéia e a Traconfide entre as regiōes sujeitas à Judéia, e depois a Agripa II, G. 3, 3, 5 \& 56: 
Gaza e outras cidades do litoral na primeira doação de Augusto (92). Outras cidades marítimas (n. 285) posteriormente desaparecem da história. Rafiah (= Rafah), ao sul de Gaza, classificada pelo geógrafo Ptolomeu como cidade da Judéia, mais tarde só se menciona como etapa na marcha de Tito de Alexandria a Cesaréia (G. 4, 11, $5 \S 662$ ) (93). Possivelmente foi absorvida por Gaza, e fazia parte do reino de Herodes, enquanto Aretusa desapareceu por completo, ignorando-se sua posição exata (94). Apolônia (= Arsuf), entre Jafa e Cesaréia, é mencionada de passagem por José (n. 285), Plínio e Ptolomeu (95). A fundação de Antípatris fora dos limites da Judéia e da Samaria (A. 16, 5, $2 \S 142$ s; G. 1, 21, 9 § 417), comprova que Herodes tinha debaixo de si todo o litoral, de Rafia a Cesaréia, excetuando Ascalão (n. 118), e não sòmente as cidades que José enumera expressamente na primeira doação de Augusto (n. 211) (96).

320. - Quanto às cidades helenísticas do interior, fora de Samaria, Hipos, Gádara, Maresa e Adora, e as que estavam situadas dentro dos territórios posteriormente cedidos a Herodes, na Gaulanítide, Batanéia, Auranítide e Paniás-Ulata, certos autores incluem ainda outras cidades da Palestina, e até mesmo a quase totalidade delas, como Gámala, Abila, Citópolis, Pela, Dium, Gérasa e Filadélfia (97). Este fato teria dado ao reino de Herodes uma extensão verdadeiramente respeitável, e teria consolidado enormemente sua posição como rei aliado e guarda das fronteiras do Império. Além disto, a Peréia, tetrarquia de Feroras (n. 247-249), teria estado inteiramente cercada por territórios sujeitos diretamente a Herodes, o que confirmaria a dignidade meramente nominal de Feroras, e falaria ainda mais a favor da cessão voluntária daquela tetrarquia . Contudo, como não se provou ainda, nem pelas fontes literárias,

(92). - Ver E. Schürer 3, 6210; W. Otto 48, nota. As enumerações de José nem sempre são completas, e nem sempre se correspondem nas passagens paralelas. Na enumeração das cidades reconstruídas por Gabínio, G. 1, 8, $4 \S 166 ; A .14,5,3 \S 88$, êle mesmo diz, que havia outras cidades mais. Na enumeração de $G$. aparecem Iâmnia e Apolônia, que se omitem na de A. Na enumeração de A. lemos Gaza, na de G. Gámala, Gábala ou Gádara, o que se deve provàvelmente a um êrro de copista.

(93). - Ptolomeu, Geographia 5, 15, 5; Políbio, Historiae 5, 80, 3.

(94). - F.-M. Abel ib. 2, mapa IX; E. Schürer 3, 68; H. St. J. Thackeray 7, 486.

(95). - Plínio, Naturalis Historia 5, 13, 69; Ptolomeu, Geographia 5, 16, 2. Ver F.-M. Abel, 1b. 2, 247; E. Schürer 3, 83; A. 13, 15, 4 § 395.

(96). - E. Schürer $3,62^{2}$.

(97). - M.-J. Lagrange 180; cf. W. Otto 116. - A. H. M. Jones 67 exclui expressamente Ábila, Citópolis, Pela, Dium e Filadélfia. Em F.-M. Abel, ib. 2, mapa IX estas cidades estāo fora dos limites do reino de Herodes. Também U. Holzmeister 177 enumera apenas Hipos e Gádara, como M. du Buit, ib. 175 . 
nem pela epigrafia ou pela numismática, que alguma daquelas cidades tenha, alguma vez, estado sujeita diretamente a $\mathrm{He}-$ rodes, é preferível continuar a considerá-las como cidades livres, embora sujeitas à província da Síria (n. 286) (98) .

321. - Os únicos argumentos em contrário são o fato de não ouvirmos falar em enclaves no reino de Herodes, como seria o caso de Citópolis, Pela, etc., que impediriam o trânsito direto entre a Peréia e os territórios nordestinos do reino, e o fato da vitória de Herodes perto de Filadélfia-Ammân durante a primeira guerra com os nabateus, quando se diz expressamente, que êstes haviam invadido território judaico (n. 196) (99). Contudo, o sistema romano não impedia a existência de enclaves no reino de Herodes, como não os impedia antes e depois dêle. Ascalão sempre continuou como enclave em território judaico (n. 118), e a Samaria durante algum tempo formava um enclave na Palestina, que dividia em duas partes a etnarquia de Hircano II (n. 287). Também a tetrarquia de Herodes Antipas estará dividida em duas partes, a Galiléia e a Peréia, separadas entre si pelos territórios de Citópolis e Pela. Deveríamos antes falar de enclaves de Herodes no território da Decápole, pelo fato de êle possuir Gádara e Hipos, e outras cidades mais (n. 211). Além disto, os enclaves em territórios dêle não impediam que seu reino formasse um único bloco contínuo desde Rafia e a Iduméia até à Auranítide. Se os nabateus faziam incursões em território judaico, Herodes por sua vez se adentrava em território nabateu (n. 196). Assim sua vitória perto de Filadélfia não fazia necessàriamente do respectivo distrito um território judaico.

322. - O primeiro dos territórios nordestinos de Herodes, em ordem geográfica, era a Gaulanítide - $\dot{\eta}$ Tavdavîtıs (G. 2, 12, 8

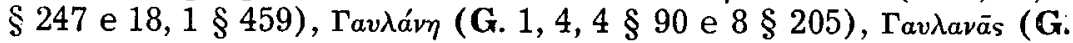
$4,1,1 \S 2$ ), ou $\Gamma a v \lambda a v i \tau i \eta^{\prime}($ G. $2,9,2 \S 168$ e $20,6 \S 574)$ - limítrofe com a Galiléia entre os lagos de Hulé e de Genesaré (G. $3,3,1 \S 37$ ), e dela separada por êstes mesmos lagos e o curso

(98). - Sabemos pelo contrário, por uma inscrição encontrada em Secia (nota 161 do capitulo precedente), que Herodes tomou posse efetiva da Auranítide, F.-M. Abel, ib. 2, 152 .

(99). - Ver ambos os argumentos em W. Otto 116. Pelo contrário diz A. H. M. Jones 67: But it is to modern ideas somewhat curious that Scythopolis and Pella, whose combined territories formed a wedge thrust between Samaria and Peraea on the south and Galilee and the territory of Gadara on the north, should have been withheld from Herod. But it was not considered necessary in antiquity that a kingdom should form a continuous block of territory. 
intermediário do Jordão (c. de $17 \mathrm{~km}$.). Limitava-se ao norte, pelo monte Hermón ( = djebel esh-Sheich, $2.814 \mathrm{~m}$; ver Ps. 132 [133], 3; 88 [89], 13); ao sul, pelo território de Hipos (n. 211) e o rio Yarmuk (= sheriat el-Menadireh); a leste, pelo rio el-Allân, que a separava da Batanéia (100). O nome da Gaulanítide deriva-se da cidade levítica de Golan (Dt. 4, 43; Jos. 20, 8 , etc.), e se conserva ainda no nome do hodierno distrito de Djolan (101). Apesar de pequena, a região dividia-se em Gaulanitide superior, com as cidades de Sogane (= el-Yehudiye), a $9 \mathrm{~km}$. a nordeste do lago de Genesaré, e Seléucia (= Seluqiye), a $15 \mathrm{~km}$. a sudeste do lago de Hulé (G. 4, 1, $1 \S 2 ; 1,4,8 \S 105$ ), e em Gaulanítide inferior, dominada pela cidade fortificada de Gámala (= Djamle), a mais forte de tôda a região, a 18 $\mathrm{km}$. a leste do mesmo lago (102). José chega a designar a Gau-

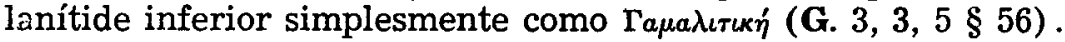
Ignora-se o paradeiro da cidade de Solyme (V. $37 \S 187 ;$ G. 4, $1,1 \S 2 ; 2,9.1 \S 168)$.

323. - A Batanéia, território relativamente pequeno, conserva em seu nome - i Baravaía ou Baravéa (G. 2,6, 3 § 95) um vestígio da antiga região de Basan ( = Bashan, a fértil; Num. 21, 33; Dt. 3, 13, etc.) (103). Limitava-se, ao norte, pelos territórios de Panéias-Ulata (n. 327) e a província da Síria; a oeste, pela Gaulanítide; ao sul, pelo território da cidade livre de Dium (n. 286) e o dos nabateus; a leste, pela Traconítide e a Auranítide (A. 17, 2, $1 \S 25$ ) (104). José pouco fala dela, mencionando-a como parte da doação de Augusto em 24/23 a. C. (n. 266), e como distrito da tetrarquia de Filipe (G. 2, 6, 3 \& 95; $\mathbf{A}$. 17, 8, 1 \$ 188 e $11,4 \S 319$ ) e do reino de Agripa II (A. 20, 7, 1 $\S 138 ;$ G. $2,12,8 \S 247.17,4 \S 421.18,6 \S 482 ; 3,3,5 \S 56)$. Várias vêzes menciona os colonos judaicos vindos da Babilônia, e estabelecidos na Batanéia por Herodes (A. 16, 2, $1 \S 23-3 \S$ 28, etc.). A cidade grega de Raphana (= er-Rafé), atribuída por Plínio à Decápole, era provàvelmente idêntica com a Raphon de 1 Mac. 5, 37, e a Arphá mencionada por José (G. 3, 3, $5 \S 57)(105)$.

(100). - F.-M. Abel, Géographie 2, 155. O Yarmuk é o Hieromices de Plínio, Naturalis Historia 5, 18, 74; ver F.M. Abel, 1b. 483.

(101). - F.-M. Abel, 1b. 1, 47s; M. du Buit, ib. 78s.

(102). - F.-M. Abel, 1b. 2, 155. 433s. 325; M. du Buit, ib. 175. Ver G. 1, 4, 8 $\S 105$ e $4,4 \S 90 ; 2,20,4 \S 568$. - Sôbre Bethsaida Julias ver a nota 72 dêste capitulo.

(103). - F.-M. Abel, ib. 1, 275; M. du Buit, ib. 175. A forma grega do nome provém da forma aramaica Bathan.

(104). - F.-M. Abel, ib. 2, 155 e mapa IX; M. du Buit, ib. 175.

(105). - Ver Plínio, Naturalis Historia 5, 18, 74; F.-M. Abel, Géographie 2, 261. 432; U. Holzmeister 180. 


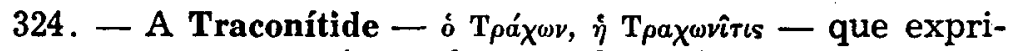
me em seu nome o caráter selvagem da região, era igualmente um distrito relativamente pequeno, limitando-se a oeste pela Batanéia (A. 17, 2, $1 \S 138$ ); ao sul, pela Auranítide; ao norte e leste, pela província da Síria (106). A cidade de Phoena (= el- Mismiye), ainda fazia parte do distrito, sendo chamada

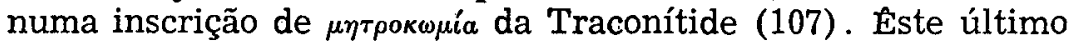
têrmo às vêzes inclui também os distritos vizinhos, igualmente de caráter acidentado e vulcânico (108). Filón e José dão a Filipe, filho de Herodes, simplesmente o título de tetrarca da Traconítide, e em Lc. 3, 1 êle é chamado de tetrarca da Ituréia (n. 328) e da região da Traconítide, quando sabemos que o era igualmente da Auranítide, da Batanéia, da Gaulanítide, de Panéias e das regiões vizinhas (109). Em geral José é exato em suas informações, porque Nicolau de Damasco, uma de suas fontes principais (n. 54), devia estar òtimamente informado sôbre a divisão administrativa do reino de seu fautor Herodes (110), ainda mais em se tratando de regiões vizinhas de seu torrão natal. Vimos que o motivo para se conceder a Traconítide a Herodes era a supressão do banditismo, favorecido pelo caráter árido e improdutivo da região (A. 15, 10, 1 § 344-346) (n. 266) .

325. - O nome da Auranítide - i A ỉpavîtıs (G. 1, 20, 4 § 398; A. $15,10,1 \S 343)$ - mostra que ela incluia dentro de seus limites o djebel Hauran, montanha de origem vulcânica, intimamente ligada à região vulcânica do el-Ledja da Traconítide (111). Os limites da região eram, a oeste, a parte in-

(106). - F.-M. Abel, ib. 2, 155s e mapa IX; M. du Buit, ib. 175. Tráchôn signtfica o terreno abrupto e acidentado, cf. G. $2,6,3 \S 95 ; A .15,10,1 \S 343$; Trachônitis em A. 17, 2, $\S 25$, etc. Comparem-se a Cilícia Traquéia Estrabäo, Geographica 14, 5, 1 [p. 668], Seléucia Traquéia (Alexandre Polihistor, citado em C. Müller, Fragmenta Historicorum Graecorum III, Parisiis 1883, 236), etc.

(107). - Corpus Inscriptionum Graecarum, n. 4551 citado por F.-M. Abel, ib. 2, 156: Ver também A. H. M. Jones, The Greek City from Alexander to Justinian, Oxford 1940, 88 .

(108). - F.-M. Abel, ib. 2, 155. Sôbre a região de el-Ledja, de caráter vulcânico, ver ib. 1, 47. 72 .

(109). - Filón, Legatio ad Gaium $41 \S 326 ;$ A. 18, 4, 5 §. 106 e 5, 4 \$ 137; G. 2, 6, 3 \$ 95. $12,8 \S 247 ; 3,10,7 \S 512 ;$ F.-M. Abel, ib. 2 156 2 .

(110). - F.-M. Abel, ib. 2, 156 .

(111), - F.-M. Abel, ib. 1, 46s. 377s. 2, 155s. O Hauran alcança $1.799 \mathrm{~m}$. de altura, as camadas de lava de 1.100 a $1.200 \mathrm{~m}$. Chama-se igualmente de djebel Druz $=$ monte dos druzos, sôbre os quals veja-se, por exemplo, E.-J. Finbert, Israël (Les Guides Bleus), Paris 1955, 53. 71s. O nome do Hauran fá aparece em Ez. 47, 16. 18, e o monte menciona-se na lista dos montes dos sinais luminosos (nota 132), em M. Rosh ha-Shanah 2, 4; Tos. RoshhaShanah II, 2a. (ed. P. Fieblg, Der Tosephtatraktat Rosh Hashshanah [Kleine Texte 130], Bonn 1914, 7); ver E. Schtirer 2, 10. 
ferior da Batanéia; ao norte, a Traconítide; ao sul, o território dos nabateus; a leste, as areias do deserto, ou, mais exatamente, o posto militar mais avançado a serviço de quem tivesse em seu poder a Auranítide. Esta continha dentro de seus limites duas cidades helenísticas, Cánata (=el-Kerak) e Cánatha (= Qanawat) (112). Nesta mesma região Herodes sofrera tremenda derrota às mãos dos nabateus e de Atenión, general de Cleópatra (n. 195). Zenodoro arrendou de Cleópatra certos territórios de Ptolomeu e Lisânias de Calcis (n. 189), a ela cedidos por Marco Antônio, e arrendou, por sua vez, a Auranítide aos nabateus por cinqüenta talentos anuais (n. 266). O fato prova, de um lado, o pouco valor econômico da regiāo (113); por outro, o fim que os nabateus deviam ter em vista ao adquirir o contrôle sôbre esta região, isto é, a participação nos lucros do banditismo, pelo assalto às caravanas da Arábia (n. 266) (114) .

326. - As últimas regiōes do reino de Herodes, Ulata Oủdá $\theta a$ - e Panéias - Пavías, Maveás - com as regiões adjacentes (A. 15, 10, $3 \S 360$; n. 267), podem ser tratadas conjuntamente, porque nada sabemos sôbre os limites que as separavam entre si, e porque às vêzes Panéias parece incluir a região de Ulata, e designar simplesmente o território cedido a Filipe, fora da Batanéia, da Traconítide e da Auranítide (A. 17, 8, 1 $\$ 189$ ) (115). O distrito limitava-se, a oeste, pelo curso do Jordão e o lago de Hulé; ao sul, pela Gaulanítide e parte da Batanéia; ao norte e a leste, pela província da Síria (116). O nome de Ulata, que parece ter dado o nome ao lago respectivo, aparece pela primeira vez na doação de Augusto em 20 a. C. (n. 267; A. 15, 10, $3 \S 360$ ). O lago de Hulé, o menor e o mais setentrional dos lagos atravessados pelo Jordão, era chamado

(112). - Admitem duas cidades distintas E. Schürer 3, 106-110; F.-M. Abel 1, 354z; id., Géographie 2, 150. Falam apenas de Canatha = Qanawat U. Holzmeister 180; M. du Buit, ib. 175. O problema será discutido mais a fundo ao tratarmos das cidades da Decápole.

(113). - A. 15, 10,2 $\$ 352$. Comparem-se os 200 talentos pagos anualmente por Jericó, e os 200 pagos igualmente a Cleópatra pelos territórios dos nabateus cedidos a ela (n. 190).

(114). - Mais tarde menciona-se na Auranitide ainda a cidade de saccaea-Maximianopolis, A. H. M. Jones, ib. 88.287.

(115) . - Em A. 17, 8, 1 \$189 só se fala em Panélas, em G. 2, 6, 3 \$ 95 em distritos de Zenodoro, perto de Panéias. Sabemos por A. 15, 10, 3 359s que Herodes recebeu na segunda doação de Augusto Panéias e Ulata, enquanto em G. $1,20,4 \S 400$ só se fala em territórios entre a Traconitide e a Galiléia .

(116). - F.-M. Abel. Géographie 156s. 158 e mapa IX; M. du Buit; lb. 175. 
pelos antigos de lago da Semeconítide ou dos Semeconitas (117), e era identificado outrora com as águas de Merom de Jos. 11, 5. 7). Os pântanos do lago, recentemente drenados, e seus juncos, eram famosos na Antigüidade (118).

327. - A região de Paniás (119), recebeu seu nome do santuário de Pã - Mavếo -, construído em cima da gruta, onde nasce o nahr Banyâs, um dos três afluentes principais que formam o rio Jordão (120). ПIavếov é pròpriamente um adjetivo neutro, que exige como complemento um substantivo correspondente, como ävrpov ou $\sigma \pi \eta \dot{\lambda} \alpha \iota \iota v=$ gruta $(121)$, ou ö pos = monte, designando a montanha que se eleva acima da gruta e do santuário (122). Mavias, por sua vez, é um adjetivo feminino, que leva consigo implicitamente o têrmo $\chi \omega$ ́́pa, significando a região tôda (123), ou, então, a palavra חódıs, significando a cidade de $\mathrm{Pa}-$ néias (= Banyâs), construida perto da gruta (124). O nome Пavєiov, que aparece pela primeira vez por ocasião da batalha entre Antíoco III e as tropas egípcias de Ptolomeu IV em 198 a. C. (n. 4), que deu aos selêucidas o domínio da Palestina, prova, ao mesmo tempo, a helenização bastante remota desta região, confirmada pela preponderância da população pagã (125). Herodes para ela contribuirá pela construção do templo de Augusto (n. 262), e seu filho Filipe empenhar-se-á no mesmo sentido pela construção da cidade de Cesaréia de Filipe ou Cesaréia Paniás (126), o que também deve ter contribuído para fa-

(117). - G. 3, 10, $7 \S 515 ; 4,1,1 \S 20 ;$ A. 5, 5, 1 \$ 199; F.-M. Abel, ib. 1, 491-494. 162. O lago tem de 5 a $6 \mathrm{~km}$. de comprido e de largo, e fica ainda a 2 m. acima do nível do mar.

(118). - D. Carpi, Compêndio de Geografia de Israel, 2. ed., Jerusalóm 1957, 42-44; F.-M. Abel, ib. 2, 491s. Ver Estrabão, Geographica 16, 2, 16 (p. 755) o qual, contudo, confunde o lago de Hulé com o de Tiberíades.

(119). - Paneas em latim, conforme Plínio, Naturalis Historia 5, 15, 71 e 18, 74.

(120). - Ver F.-M. Abel, Géographie 1, 161s. Sôbre as origens do Jordão no lago de Phiala (= copa, devido à sua forma redonda), hoje birket er-Ram ou Ran (628 por $476 \mathrm{~m}$.), a c. de $11 \mathrm{~km}$. de distâncta, segundo G. $1,21,3 \S$ $404-406 ; 3,10,7 \S 509-515$, ver ib. $1,161^{1}$. $489 \mathrm{~s}$.

(121). - Ver G. 1, 21, $3 \S 405 ; 2,11,3 \S 404 ; 3,10,7 \S 509,513 \mathrm{~s} ;$ A. $15,10,3 \S 363 \mathrm{~s}$.

(122). - Ver G. 1, 21, $3 \S 405$ e Eusébio de Cesaréia, Historia Ecclesiastica, 1. 7, c. 17 (PG 20, 680A); E. Schürer 3, 132336. - H. St. J. Thackeray 2, 190 pensa no monte Hermón $=$ djebel esh-Schetch.

(123). - Ver A. 15, 10, $3 \S 360 ; 17,8,1 \S 189 ;$ G. 2, 9, $1 \S 168$; Plínio, Naturalis Historia 5, 18, 74: Paneas in qua Caesaraea. - Contudo, 1b. 5, 15, 71 parece pensar na fonte do Jordão, quando điz: Jordanes amnis oritur e fonte Paneade.

(124). - Ver A. 18, 21 \& 28; E. Schürer 3, 133338.

(125). - E. Schürer 3, 133. Ver Políbio, Historiae 16, 18, 2 e 28, $1,3$.

(126). - Ver Mt. 16, 13; Mc. 8, 28; A. $20,9,4 \S 211 ; 18,2,1 \S 28 ;$ V. $13, \S 74 ;$ G. 3 , $9,7 \& 443 ; 7,2,1$ \& 23; Ptolomeu, Geographia 5, 14, 17. 
vorecer o ascendente da Panéiade sôbre o resto da região (127). Vimos que Panéias-Ulata havia feito parte dos territórios de Zenodoro, sucessor de Lisânias no govêrno da Ituréia (n. 267). Este fato justifica a expressão de Lc. 3 , 1, onde se dá a Filipe o título de tetrarca da Ituréia e da Traconítide, se bem que na mesma época, conforme refere o mesmo texto, outra parte da Ituréia, a Abilene, estivesse em poder de outro Lisânias (128).

328. - III. Superfície e população do reino de Herodes. - Quando Herodes, em 12 a. C., nomeou sucessores seus os filhos Antípater, Alexandre e Aristóbulo (n. 238), afirmou que a extensão de seu reino bastaria para ser dividido entre um número ainda maior de filhos (G. 1, 23, $5 \S 458$ ). Também Augusto, antes de pronunciar-se sôbre os direitos respectivos de Arquelau, Antipas e Filipe, nomeados sucessores no último testamento do pai (G. 1, 33, 7 § 664; A. 17, 8, 1 § 188s), refletiu, em particular, sôbre a decisão a tomar, tendo em conta a extensão do reino, o total de suas entradas, e o número dos filhos de Herodes (G. $2,2,4 \S 25)$, decidindo, afinal, dividí-lo entre os três mencionados (G. 2, 6, $3 \S 93 \mathrm{~s} ;$ A. $17,11,4 \S 318 \mathrm{~s} ;$ n. 247). Será útil, diante disto, e em vista de uma compreensão mais fácil de certos aspectos do govêrno de Herodes, examinar brevemente a extensão aproximada dos territórios sujeitos a êle. Teremos presente, dêste modo, o fato de que a Palestina, na realidade, não passava de uma faixa de terra cultivável relativamente estreita, situada entre as águas do Mediterrâneo, e as areias do deserto arábico. O conhecimento de suas verdadeiras proporções ajudar-nus-á a compreender, que sua importância se avaliava, em primeiro lugar, sob o aspecto estratégico e político, e que

(127). - E. Schürer 3, 135 e 2, 103, sôbre os territórios nordestinos de Herodes em geral. Estrabão, Geographica 16, 2, 16 e 20 (p. 755s) menciona a Traconitide, bem como Plínio, Naturalis Historia $5,18,74$. A Batanéla é mencionada por Políbio, Historiae 16, 39, 3 e Ptolomeu, Geographia 5, 14, 20, o qual também fala dos árabes da Traconitide.

(128). - Durante muito tempo via-se em Lc. 3, 1 uma confusão com Lisânias, filho de Ptolomeu de Calcis, executado em 37-6 a. C. (n. 189). Encontraram-se, porém, duas inscrtções perto de Suq wadı Barada, a antiga Ablla, em que se menciona um tetrarca Lisânias, e se fala dos Senhores Augustos. Estes só podem ser Tibério e Lf́la, que recebeu o título de Augusta depois da morte de seu marido. As inscrições devem por conseguinte, datar de entre 14 d. C., ano da morte de Augusto, e $29^{\circ}$ d. C., ano da morte de Lívia. Do mesmo modo diz José, que Calígula deu a Agripa I, entre outros territórlos, a tetrarquía de Lísânias, $A .18,7,10 \$ 237$, na qual fol confírmado por Cláudio, A. 19, 5, 1 § 275: Áblla de Lisânias, cf. G. 2, 18, 8 § 247: Lysaníou basileía. Ver E. Gabba, Iscrizioni (ver n. 81) 46-49; E. Schürer 2, 337; V. Ehrenberg-A. H. M. Jones. Documents (ver n. 81) 95, n. 180; R. Savignac, Texte complet de l'inseription d'Ablle relative a Lysanias, Revue Blblique, N. S. 9 (1912) 533-540; F.-M. Abel, Géographle 2, 158; U. Holzmeister 123, etc. 
os antigos aplicavam outros padrões, que não os nossos, para justificar a existência de pequenos estados indepedentes.

329. - Aos olhos dos romanos, em particular, não sòmente vigorava o axioma do divide et impera (n. 221), mas ainda a consideração prática, de que a multiplicação de principados minúsculos prometia uma administração local mais eficiente, e maior prontidão na defesa das fronteiras do Império, razão última da existência de semelhantes estados (n. 299) (129). Acresce que os transportes mais primitivos da época faziam parecer maiores as distâncias e dimensões geográficas aos olhos dos antigos, do que aos nossos, uma vez que, hoje em dia, por via férrea, em poucas horas poder atravessar-se o país em tôdas as direções, sem falar das vantagens do tráfego motorizado (130). Mesmo assim José nos informa que o caminho mais comum e mais rápido entre a Galiléia e Jerusalém, passando pela Samaria, levava apenas três dias (V. 52 § 269; cf. A. 20, 6, 1 $\S 118$ ), o que deve entender-se de dias de marcha, uma vez que as fontes rabínicas calculavam em $60 \mathrm{~km}$. a distância média que um homem percorre por dia (131). De resto, supria-se por meio de sinais luminosos a demora nas comunicações diretas (132).

330. - Durante o mandato inglês (1922-1948) calculava-se a superfície da Palestina, que se restringia, então, à Cisjordânia, da fronteira da atual República Libanêsa até ao gôlfo de Aqaba, em c. de $23.000 \mathrm{~km}^{2}$, a da Transjordânia, a parte mais considerável do posterior Reino Hashemita do Jordão, em c. de

(129). - Fol Diocleciano quem mais subdividiu as provincias romanas, tendo em mira o mesmo fim; A. H. M. Jones, The Greek City from Alexander to Justinian, Oxford 1940, 148.

(130). - Conforme o horário dos trens de Israel de 16.5.56 val-se de Jerusalém a Haifa em 3 horas e 33 minutos, a Tell-Aviv em 2 horas, de Tell-Aviv a Birsheba em 2 horas e 10 minutos.

(131). - Mekhiltah Exodus 16, 13 (57a): a viagem de um dia são dez parassangas $=60 \mathrm{kms}$; palBerakhoth 1, 2c, 46: um homem comum anda 40 'mil' $=60$ kms. por dia; babPesachlm 93b: 40 'mil' $=60 \mathrm{kms}$. Ver H. L. Strack-P. Blllerbeck 2, 149, e Lc. 2 44; Jo. 2, 1 . Em M. Maaser Shent 5, 2 calcula-se um dia de marcha a Jerúsalém: de Elath (?), ao sul; de Acraba, ao norte; de Lida, a oeste; do Jordão, a leste, lugares de $30-40 \mathrm{kms}$. de distância. Ver também em Act. 23, 23. 31s a marcha dos soldados romanos, da cavalaria e infantaria, com São Paulo, de Jerusalém a Antf́patris.

(132). - Sôbre a transmissāo de sinais luminosos de Jerusalém para anunclar os inicios dos meses, etc., ver F.-M. Abel, Gégraphie 1, 377 (Montagnes des Stgnaux); U. Holzmeister, Chronologla 185; M. Rosh ha-Shanah 2, $4 \mathrm{~s}$. Tais sinais se transmitlam até à Babllónia. Veremos que as diversas fortalezas de Herodes eram visivels umas das outras; cf. G. Lankester Harding, The Antiquities of Jordan, London 1959, 105. 
$45.000 \mathrm{~km}^{2}$ (133). Calculando os limites históricos médios da Palestina, que se supõem na Bíblia, isto é, na Cisjordânia, do Líbano até à cidade de Bersabé no Neguev, e, na Transjordânia, do rio Yarmuk até às alturas do mar Morto, teríamos para a primeira entre 15 e $16.000 \mathrm{~km}^{2}$, para a segunda entre 9 e 10.000 $\mathrm{km}^{2}$, o que daria para a Palestina tôda, enquanto ela nos interessa para a história dos tempos do Novo Testamento, a superfície de 24 a $26.000 \mathrm{~km}^{2}$. Dêste total devem, todavia, descontar-se os distritos da Palestina, que não faziam parte dos domínios de Herodes, isto é, os territórios das cidades da Decápole (n. 320), das de Dora (= el-Burdj) e Ptolemaide (= Acco), sujeitas à província da Síria (n. 286), o da cidade livre de Ascalão (n. 118. 321), e o da cidade de Bersabé (= Birsheva) no Neguev, sujeita, então, aos nabateus. (134). Devem acrescentar-se, em compensação, os territórios nordestinos de Herodes, que se estendiam, de oeste a leste, do lago de Genesaré até ao djebel Hauran (n. 318), mas cuja delimitação exata ao norte e ao sul nos é desconhecida. Em resumo: podemos supor que os territórios sujeitos a Herodes alcançavam mais ou menos a mesma cifra de 24 e $26.000 \mathrm{~km}^{2}$ (135).

331. - A frase bíblica clássica para descrever os limites históricos médios da Palestina, de norte a sul, é aquela que diz: de Dan a Bersabé (136). A distância de Dan (= tell el-Qadi) perto de Banyâs (n. 328), até Bersabé, é de $240 \mathrm{~km}$. em linha reta, enquanto a maior largura da Cisjordânia, entre o mar Morto e o Mediterrâneo, ao sul de Gaza, corresponde a c. de 125 $\mathrm{km}$. Desta forma a Cisjordânia, transplantada para o Estado de São Paulo, corresponderia, em sua maior largura, à distância aproximada entre Santos e Jundiaí, e em seu maior comprimento, à distância entre São Paulo e Cruzeiro $(246 \mathrm{~km}$. por via férrea). Podemos, pois, imaginar-nos o desenrolar da maior parte dos acontecimentos da história bíblica do Antigo e do Novo Testamento, num espaço, que cabe cômodamente naquela parte do Estado de São Paulo, que se estende de sua capital

\footnotetext{
(133). - P. Vidal de la Blache - L. Gallois, Géographie Universelle VIII, Paris 1929, 214.

(134). - F.-M. Abel, Géographie 2, 263 e mapa IX.

(135). - Comparem-se: Suíça $41.288 \mathrm{~km} 2$; Bèlgica $30.507 \mathrm{~km} 2$; Portugal $88.608 \mathrm{~km} 2$; Sicflla $25.426 \mathrm{~km} 2$; Alagoas $28.571 \mathrm{km2}$; Sergipe $21.552 \mathrm{~km} 2$; Marajó e ilhas $60.302 \mathrm{~km} 2$; ver Der Grosse Brockhaus, 16. ed., Wiesbaden 1953-1957, nos respectivos lugares; Anuário Estatístico do Brasil IV, Rio de Janeiro $1938,13$.

(136). - 1 Sam. 3, 20; 2 Sam. 3, 10; 24, 2. 5; 3 Reg. 5, $5(4,25) ; 2$ Par. 30, 5. Ver F.-M. Abel, Géographie 1, 307; M. du Buit. ib. 136 .
} 
em direção ao Estado do Rio de Janeiro (137). O Estado de São Paulo pode servir, além disto, para ilustrar o quadro geográfico da Palestina, e sobretudo da Judéia pròpriamente dita, porque, depois de uma planície relativamente estreita, o terreno se ergue quase abruptamente até à altura de $800 \mathrm{~m}$., assim como na Palestina, da planície marítima de Sharon e da Shephelah, de 15 a $20 \mathrm{~km}$. de largura, passa-se abruptamente às colinas da Samaria e da Judéia, e à montanha de Judá, de 800 a $850 \mathrm{~m}$. de altura (138).

332. - Além das dimensões geográficas do reino de Herodes convém ter diante dos olhos, para melhor compreensão de nossa história em certos de seus aspectos, uma idéia, ao menos aproximada, da população da Palestina na época do Novo Testamento. Se as informações de José a êste respeito se ressentem de exagêros graves (n. 58), há, contudo, dados seus perfeitamente verossímeis; que hoje em dia, graças à arqueologia e geografia bíblicas, podem ser controlados, e que encontram sua confirmação na reabilitação do país, que se vem operando. desde a volta dos judeus à terra de seus pais. Falando da Galiléia, informa-nos José, que seus habitantes sempre haviam sabido resistir às incursões inimigas, porque desde a infância estavam afeitos à guerra, e sempre haviam sido numerosos. Nunca faltara coragem aos homens, e nunca faltaram homens ao país (G. 3, 3, 2 § 41s). Condição semelhante prevalecia na Samaria e na Judéia, porque, segundo êle, a prova mais segura das virtudes e da prosperidade das duas províncias era o fato de se acharem densamente povoadas. E' difícil dizer, se êle se refere aqui às virtudes naturais do homem, ou à convicção, co-

(137). - De certo modo pode dar-se razăo a $\mathrm{S}$. Jerônimo, quando zomba da pequenez da terra dos judeus, habitada, ainda mais, em grande parte por estrangeiros, do modo seguinte: Respondeant mihi qui hanc terram... possessam putant a populo Judaeorum, postquam reversus est ex Aegypto, quantum possederit; utíque a Dan usque Bersabee, quae vix centum sexaginta millium in longum spatio tenditur. Neque enim David et Salomon potentissimos reges, exceptis iis quos post victoriam in amfcitiam receperunt, plus tenuisse Scriptura testatur. Et hoc dico, ut taceam quinque Palaestinae civitates, Gazam, Ascalonem, Geth, Accaron et Azotum: Idumaeos quoque a meridiana plaga vix septuaginta quinque millibus ab Jerosolyma separatos, Arabas et Agarenos quos nunc Sarracenos vocant, in vicinia urbis Jerusalem. Pudet dicere latitudinem terrae repromissionis, ne ethnicis occastonem blasphemandi dedisse videamur. Ab Joppe usque ad viculum nostrum Bethleem, quadraginta sex millia sunt, cui succedit vastissima solitudo, plena ferocium barbarorum... Haec est, Judaeae, tuarum longitudo et latitudo terrarum; in his gloriaris, super his te per diversas provinctas ignorantibus jactitas (Epistola 129, 4 [PL 22, 1104]). - S6́bre outras Indicaçōes de limites da Palestina, prometidos ou históricos, ver F.-M. Abel, Géographie 1, 299-310.

(138) . - M. du Buit, ib. 74-76. 
mum no Antigo Testamento, de que os filhos são a recompensa de Deus pela observância da Lei e de seus preceitos (139). Consta, contudo, que o povo judaico sempre foi extremamente prolifico, e que se urgia que os homens contraissem matrimônio o mais cêdo possível (140). A Peréia, por seu lado, descreve-se como um país árido e acidentado, e avêsso à cultura de produtos mais delicados (G. 3, 3, $3 \S 44 \mathrm{~s} ; n$. 314), o que, naturalmente, devia contribuir para uma diminuição do afluxo de habitantes.

333. - Sabemos, contudo, pela Bíblia, por José, e pela arqueologia, que a Peréia, assim mesmo, foi outrora um país relativamente próspero. As pesquisas arqueológicas revelaram o fato surpreendente, que nesta região, como em tôda a Transjordânia, existiam outrora inúmeras cidades prósperas, que floreciam, graças a um extenso sistema de irrigação, servido por abundantes aquedutos, açudes, etc., que só desapareceram depois da invasão árabe. Sabemos pela Bíblia, que as tribos de Ruben e Gad, ricas em gado, solicitaram de Moisés a entrega da região de Galaad, por ser muito fértil, e própria para a criaçâo de gado (Num. 32, 1-5) (141). As investigações arqueológicas provaram, outrossim, que no Neguev, a parte meridional desértica de Israel, existiam outrora centenas de cidades e vilas de tôdas as épocas, que floresceram até aos fins da época bizantina (142). Poucos anos de recuperação conseguiram elevar o número de seus habitantes a 100.000 sôbre 2.000 .000 de israelís (143).

334. - Sabemos pela história que a desolação das cercanias de Jerusalém se deve, sobretudo, à guerra de 66-70 d. C., quando as tropas romanas de Tito, para erigir e manter a circun-

\footnotetext{
(139). - Ver D. Buzy, Saint Jean-Baptiste, Paris 1922, 7s e Gen. 49, 25; Dt. 7, 14; 28, 11; Ex. 23, 26; Ps. 127 (126), 3, etc.

(140). - Em M. Aboth 5, 21 recomenda-se o matrimónio aos dezolto anos. Hecateu de Abdera (s. IV-III a. C.), conforme Dlodoro Sfculo, Bibliotheca Historica 40, 3, 8 chamava os judeus de Génos polyanthrôpon; conforme José, Ap. 1, $22 \S 194$ đe polyanthrôp6taton génos.

(14̣1). - Na concessão definitiva, ib. 33-42, acrescenta-se a metade da tribo de Manassés. Galaad muitas vêzes designa simplesmente a Transjordânia habitada por Israelitas, entre o Yarmuk e o Yabboq; Jdc. 10, 8. 18s; 11, 5. 7-11; etc.; F.-M. Abel, Géographie 378; M. du Buit, ib. 199s.

(142). - M. Avi-Jonah, Ruinas cristlanas reclén descubiertas en el Neguev, Notfcias Cristianas de Israel 10 (1959) 23; N. Glueck, Rivers in the Desert, New York 1959, $X$ (London 1959, $X$ ): In the course of the last half dozen years we have been able to place on the map the locations of about four hundred sites, of distant centuries, which belonged to welldeveloped ctvilizations reaching far beyond the confines of the Negev.

(143). - R. Dafni, The Neger (Israel Today 6), Jerusalém 1958, 21.
} 
valação ao redor da cidade, e construir as torres de assalto, tiveram que abater tôdas as árvores das redondezas, e se viam obrigadas a ir buscar madeira até à distância de 90 estádios $=$ c. de $17 \mathrm{~km}$. (G. 5, 12, 4 § 522s) (144). Se Israel, com seus $20.850 \mathrm{~km}^{2}$, é capaz hoje em dia de sustentar dois milhões de habitantes, a Palestina tôda, nas condições geográficas e climáticas de outros tempos, quando ela era capaz de suprir as necessidades de outros distritos (Act. 12, 20), e quando era gabada como a terra que manava leite e mel (Ex. 3, 8; Lev. 20, 24) (145), devia poder sustentar ao menos o dôbro, e podemos dar crédito a Filón, quando nos diz que a Diáspora deve sua origem à superpopulação da Palestina (146). A Diáspora, por sua vez, longe de constituir um enfraquecimento do povo judaico, representava uma fôrça coesa, que se calcula em seis a sete milhões, sôbre 54 a 55 milhões de habitantes de todo o Império, fôrça que, por vêzes, se fêz sentir consideràvelmente $(147)$.

335. - Os números exagerados de José podem, contudo, servir de base para um cálculo aproximado dos habitantes da Palestina de então, completados por outros dados mais verossímeis, que êle mesmo nos fornece. E' certamente difícil supor que sòmente na Galiléia, a quinta ou a sexta parte dos domínios de Herodes, pudesse haver 3.060 .000 habitantes, como José nos quer fazer crer, dizendo que aquela província continha 204 cidades e vilas, das quais a menor contava com mais de 15.000 habitantes (V. $65 \S 235$; G. $3,3,2 \S 43$; n. 58). Durante a Páscoa de 66 d. C. ter-se-iam encontrado em Jerusalém, sem considerar as pessoas impuras, não admitidas à ceia pascoal, 2.556.000 judeus (G. 6, 9, $3 \S 423-426$ ). Para calcular

(144). - o estádio calcula-se em $192 \mathrm{~m}$., W. Bauer, Griechisch-deutsches Worterbuch zu den Schriften des Neuen Testaments und der übrigen urchristlichen Literatur, 4. ed. Berlin 1952, 1390. José nos dá a mesma informação em G. 6, $1,1 \S 5$, eriquanto em 6, 2, $7 \S 151$ e 8, $1 \S 375$ fala em cem estádios, o que daria mais de 19 quilómetros. Também Plínio, o Velho, Naturalis Historia 5, 17, 13 diz: Infra hos Engada oppidum fuit, secundum ab Hierosolymis fertilitate palmetorumque nemoribus, nunc alterum bustum = Abaixo dêstes (dos essêntos) ficava a cidade de Engadi (sôbre - mar Morto), a segunda depois de Jerusalém em fertilidade e bosques de palmeirais, agora um lugar de ineêndios e ruínas como aquela. A passagem confirma o que dissemos no texto sôbre a fertilidade dos arredores de Jerusalém. Sôbre as duas fontes perto da cldade, Gulhon e Aln Roguel, canais e aquedutos, ver $L$. H. Vincent-A. M. Steve, Jérusalem (ver n. 82) 260-312.

(145). - Ver E. Power, Terra lac et mel manans, Verbum Domini 2 (1922) 52-68.

(146). - De Vita Mosis 2, $42 \S 232$; De Specialibus Legibus $1,27 \S 133$ e $38 \S 141$; J. Juster 1, 2103.

147). - J. Juster 1, 209-212. 
êste número Céstio Galo, governador da Síria, teria feito contar os cordeiros pascoais, multiplicando o número por dez, número mínimo de participantes na ceia pascoal, podendo, todavia, êste número elevar-se até vinte (148). Três milhões de judeus ter-se-iam apresentado em Jerusalém ao mesmo Céstio Galo, para queixar-se do procurdor Géssio Floro (G. 2, 14, 3 $\S 280)$. 1.100 .000 judeus teriam perecido durante o assédio de Jerusalém, em dois anos apenas, e 97.000 teriam sido feito prisioneiros (G. 6, 9, $3 \S 420)$ (149). - José é mais sóbrio quando nos informa que na festa de Pentecostes de 4 a. C., uma multidão inumerável de judeus, vindos da Galiléia, da Iduméia, de Jericó e da Peréia, juntando-se aos da Judéia, que formavam a maioria, assediaram as tropas de Sabino, procurador das finanças da Síria (G. 2, 3, 1 § 43).

336. - Em outras passagens José apresenta números concretos mais verossímeis. Conta-nos que Herodes transferiu para a Samaria 6.000 colonos, e outros 3.000 , oriundos da Iduméia, para a Traconítide (G. 1, 21, $2 \S 403$; A. 16, 9, $2 \S 285$ ) (150). Tal transferência entende-se sòmente em regiões não demasiadamente povoadas, sobretudo na Traconítide, onde deviam formar um núcleo estabilizador. Seiscentos judeus da Babilônia foram transferidos com suas famílias para a Batanéia com 0 mesmo fim (A. 17, $2,1 \S 23-3 \S 28$ ), o que seria absurdo, se se tratasse de uma região densamente povoada. Lemos, ainda, que muitos outros judeus, desejosos por poder observar mais exatamente as leis paternas, se lhes juntaram, o que prova que a região ainda oferecia possibilidades de colonização. Depois da morte de Herodes, 2.000 veteranos seus se revoltaram na Iduméia, e o total de rebeldes se elevou a 10.000 (G. $2,4,1 \S$ 55 e $5,3 \S 76)$. Tal número não poderia representar perigo sério, se o país todo apresentasse uma população que correspondesse, de algum modo, à densidade da população que José indica para a Galiléia. Tomando em consideração os costumes bárbaros da época, são ainda perfeitamente verossímeis os números de 20.000 judeus massacrados, em 66 d. C., em Cesarëia

(148). - José, lb., dá o número de 2.700 .000 pessoas.

(149). - Tácito e Suetônlo forneceriam o número mais verossímil de 600.000 mortos, conforme Paulo Osório, Historiarum Adversum Paganos Libri VII, 1. 7, c. 9, 7 (PL 31, 1084B-1085A; Corpus Scriptorum Ecclesiasticorum Latinorum 5, 460): Sexcenta millia Judaeorum eo bello interfecta Cornelius et Suetonius referunt. - - Tácito, Historiarum 5, 13 fala apenas de 600.000 sitiados, e Suetônio não indica número algum.

(150) - A êstes números devem acrescentar-se as famillas dêstes colonos. Seria para estranhar que se escolhessem precisamente 6.000 , respectivamente 3.000 pessoas, contando os colonos com os membros de suas famílias. 
(G. $2,18,1 \S 457$ ), o que representava tôda a população judaica da cidade; de 8.400 massacrados por Céstio Galo em Jafa (G. $2,18,10 \S 508$ ), cidade prevalentemente judaica, e tomada de surprêsa; de 2.000 massacrados perto de Asamon na Galiléia (G. ib. § 511).

337. - Descontando, pois, os exageros de José, de um lado, mas, de outro, tomando em consideração as circunstâncias concretas do govêrno de Herodes, e as condições climáticas da época, podemos supor, nos tempos do Novo Testamento, uma população de bem cinco milhões de habitantes para tôda a $\mathrm{Pa}$ lestina, isto é, como calculamos acima, sôbre $24-26.000 \mathrm{~km}^{2}$ (n. 331) (151). Isto representaria uma densidade de população pouco inferior à da Bélgica de hoje (152). Certamente êste número é muito mais verossímil, diante do que ficou exposto, do que o de 700.000 habitantes, mantido por alguns autores (153), e que não corresponderia sequer à população da Palestina cisjordânica durante o mandato inglês, conforme o censo realizado em 1922 (154).

338. - Esta população distribuia-se, naturalmente, de modo desigual pelo país todo, sendo mais densa na Galiléia, Samaria e Judéia, do que na Peréia e nos distritos nordestinos do reino de Herodes. Grande parte dela concentrava-se em Jerusalém e em outras cidades, como Jericó e Fasaelis, Cesaréia e Antípatris, Jafa, Iâmnia e Gaza, Samaria, Séforis, etc. (155). Jerusalém por si só deve ter possuído bem mais de 100.000 habitantes, quando, já no século IV-III a. C., Hecateu de Abdera lhe dá a população de 120.000 habitantes sôbre um perímetro de 50 estádios $=9.600 \mathrm{~m}$. Agatárquides de Cnidos (século II a. C.) chama-a de cidade forte e grande. Timocares (?) lhe atribui o perímetro de 40 estádios $=7.680 \mathrm{~m}$., como também o autor de Epístola apócrifa de Aristéias. José fala em 33 estádios $=6.336 \mathrm{~m}$., enquanto o agrimensor da Síria do século II a. C., citado por Eusébio de Cesaréia, fala apenas em

(151). - J. Juster, 1, 210² J. Felten 1, 35.

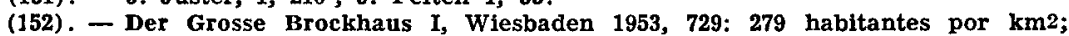
Encyclopaedia Britannica III, Chicago-London 1952, 352: 713 habitantes por milha2.

(153). - Por exemplo, por A. Harnack, citado em J. Juster, ib.

(154). - P. Vidal de la Blache-L. Gallois, ib. 214.

(155). - Gaza por si só tinha 500 conselheiros (A. 13, 13, $3 \S 364$ ), como Tíberíades terá 600 (G. 2, 21,9 $\$ 641$ ). Por outro lado, o número de conselheiros não é um indício seguro para calcular a população de uma cidade, porque no Orlente o número daqueles, em geral, era elevado, e o número de 600 era normal nas cldades da Síria; A. H. M. Jones, The Greek City from Alezander to Justinian, Oxford 1940, 176. 
27 estádios $=5.184 \mathrm{~m}$. (156). Hoje a cidade velha de Jerusalém, em mãos dos jordanianos, e depois de expulsa a população judaica, conta com c. de 70.000 habitantes, sôbre menos de um $\mathrm{km}^{2}$ (157).

339. - Note-se, contudo, que nem todos os habitantes da Palestina nos tempos do Novo Testamento eram súditos de Herodes. Devem descontar-se daqueles cinco milhões os habitantes das cidades livres e prósperas de Ascalão, Dora e Ptolemaide, e das cidades da Decápole em geral, com os seus respectivos territórios. Todavia, apesar de não possuirmos dados mais exatos, e baseando-nos apenas em cálculos aproximativos, tomando em conta as condições geográficas e climáticas daquela época, confirmadas pelas experiências da colonização atual, não estaremos muito longe da realidade se atribuirmos a Herodes o número aproximado de bem quatro milhões de súditos. Com efeito, um número consideràvelmente menor não explicaria certos aspectos de seu govêrno, como, por exemplo, as somas imensas de que dispunha, e que, em grande parte, deviam provir dos impostos e taxas pagas por seus súditos. Não explicaria, outrossim, o grande número de tropas e esbirros, espalhados pelo país, e que devem calcular-se em vários milhares.

\title{
(Continua no próximo número).
}

\author{
D. JOÃO MEHLMANN O.S.B. \\ da Pontifícia Universidade Católica de São Paulo e professor- \\ visitante da Faculdade de Filosofia, Clências e Letras da \\ Universidade de São Paulo.
}

(156). - Ver Hecateu de Abdera em Ap. 1, $22 \S 197$; Agatárquides de Cnidos em A. 12, 1, 1 6, cf. Ap. 1, $22 \$ 20$; Timocares em Eusébio de Cesaréia, Praeparatio Evangelica, 1. 9, c. 35 (PG 21, 756A); Epístola de Aristéias $\S 105$; G. 5, 4.3 \& 159 e Eusébio, tb., c. 36 (ib. 756B-C). Ver também H. St. J. Thackeray 1, 242s; C. Müller, Fragmenta Historicorum Graecorum III, Parisils 1883, 196s. 209, conforme o qual o agrimensor da Síria poderia ser Xenofonte de Lámpsaco, citado por Plínio, Naturalis Historia 4, 13, $95 ; 6,31,200$, etc.

(157). - E. J. Finbert, Israël (Les Guides Bleus), Paris 1955, 315. 339 indica 70.000 habitantes sóbre $0,850 \mathrm{~km} 2$. B. Meistermann Guide de Terre Sainte, 3. ed., Paris 1935, 110 dava 105.000 habitantes para a cidade intelra, baseado no censo de 1933 . 